\title{
Spatial variation of environmental impacts of regional biomass chains
}

\author{
F. van der Hilst ${ }^{\mathrm{a}, \mathrm{d}, *}$, J.P. Lesschen ${ }^{\mathrm{b}}$, J.M.C. van Dam ${ }^{\mathrm{a}}$, M. Riksen ${ }^{\mathrm{c}}$, P.A. Verweij ${ }^{\mathrm{a}}$, \\ J.P.M. Sanders ${ }^{\mathrm{d}}$, A.P.C. Faaij ${ }^{\mathrm{a}}$ \\ a Department of Science, Technology and Society, Copernicus Institute, Science Faculty of Utrecht University, Budapestlaan 6, 3584 CD Utrecht, The Netherlands \\ ${ }^{\mathrm{b}}$ Alterra, Team Soil Quality and Nutrients, Wageningen University and Research Centre, PO Box 47, 6700 AA Wageningen, The Netherlands \\ ${ }^{c}$ Land Degradation and Development Group, Wageningen University and Research Centre, PO Box 47, 6700 AA Wageningen, The Netherlands \\ d Valorisation of Plant Production Chains, Wageningen University and Research centre, PO Box 17, 6700 AA Wageningen, The Netherlands
}

\section{A R T I C L E I N F O}

\section{Article history:}

Received 9 May 2011

Accepted 6 January 2012

Available online 17 February 2012

\section{Keywords:}

Bioethanol

Environmental impacts

GIS

Miscanthus

Sugar beet

\begin{abstract}
A B S T R A C T
In this study, the spatial variation of potential environmental impacts of bioenergy crops is quantitatively assessed. The cultivation of sugar beet and Miscanthus for bioethanol production in the North of the Netherlands is used as a case study. The environmental impacts included are greenhouse gas (GHG) emissions (during lifecycle and related to direct land use change), soil quality, water quantity and quality, and biodiversity. Suitable methods are selected and adapted based on an extensive literature review. The spatial variation in environmental impacts related to the spatial heterogeneity of the physical context is assessed using Geographical Information System (GIS). The case study shows that there are large spatial variations in environmental impacts of the introduction of bioenergy crops. Land use change (LUC) to sugar beet generally causes more negative environmental impacts than LUC to Miscanthus. LUC to Miscanthus could have positive environmental impacts in some areas. The most negative environmental impacts of a shift towards sugar beet and Miscanthus occur in the western wet pasture areas. The spatially combined results of the environmental impacts illustrate that there are several trade offs between environmental impacts: there are no areas were no negative environmental impacts occur. The assessment demonstrates a framework to identify areas with potential negative environmental impacts of bioenergy crop production and areas where bioenergy crop production have little negative or even positive environmental impacts.
\end{abstract}

(c) 2012 Elsevier Ltd. All rights reserved.

\section{Contents}

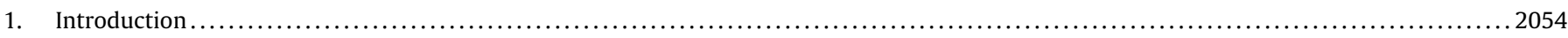

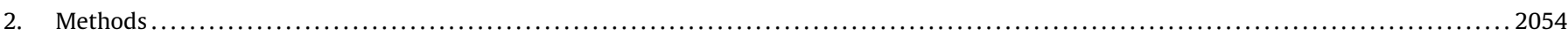

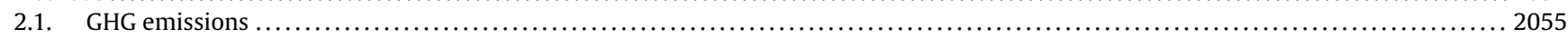

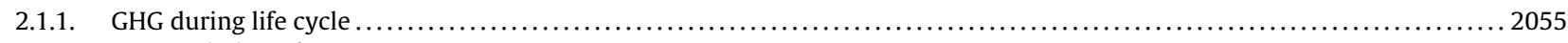

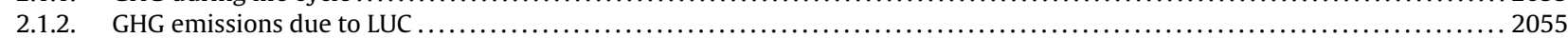

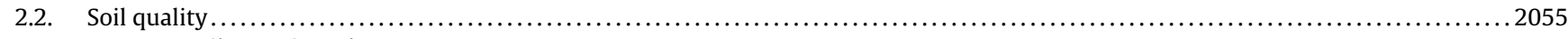

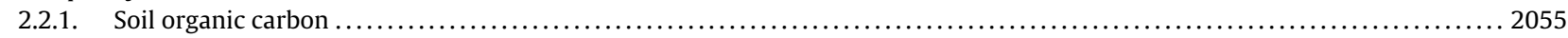

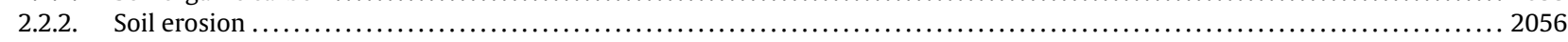

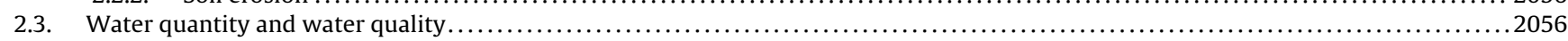

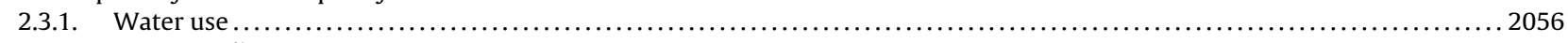

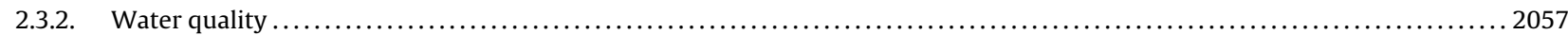

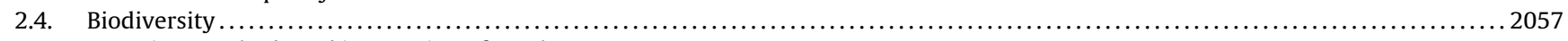

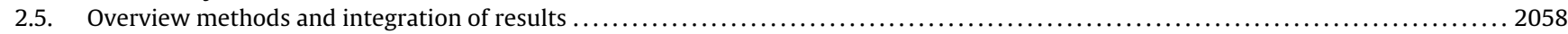

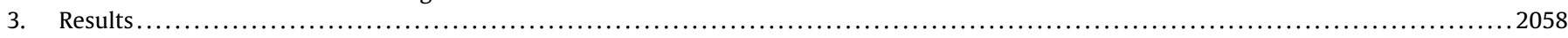

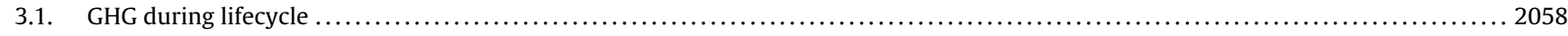

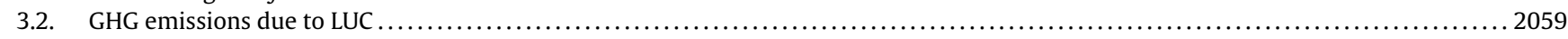

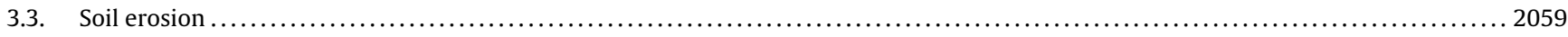

\footnotetext{
* Corresponding author at: Department Energy \& Resources, Copernicus Institute of Sustainable Development, Faculty of Geosciences, Utrecht University, Budapestlaan 6, 3584 CD Utrecht, The Netherlands. Tel.: +31 030253 7609; fax: +31 0302537601.

E-mail address: f.vanderhilst@uu.nl (F. van der Hilst).
} 


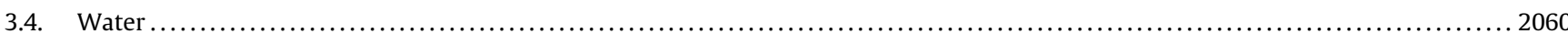

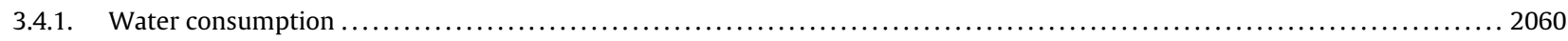

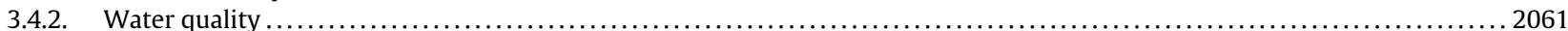

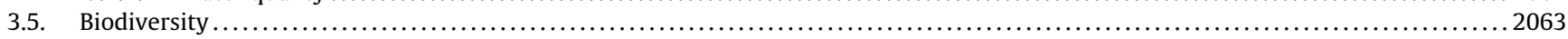

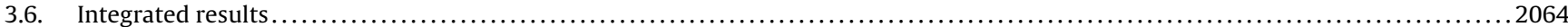

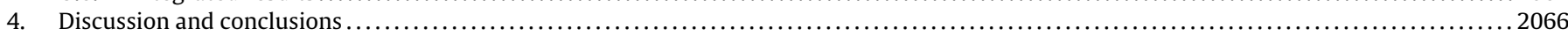

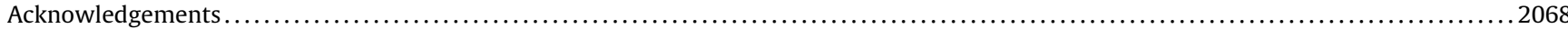

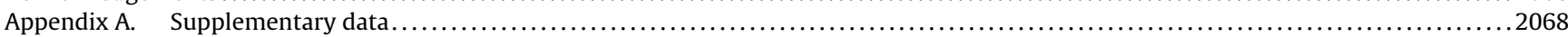

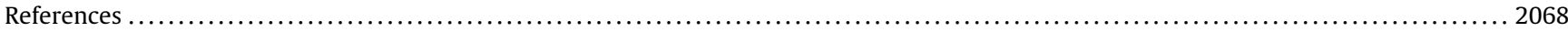

\section{Introduction}

In recent years, sustainability issues related to bioenergy have increasingly become a point of discussion in scientific, public and political arenas. At several levels, initiatives for sustainability criteria, codes of conduct and protocols have been developed to deal with this issue [1-5]. The steps towards sustainable biomass certification system are well described by Lewandowski and Faaij [6] and van Dam et al. [7,8]. However, sustainable bioenergy criteria are currently hardly implemented in (inter-) national policies. In addition, initiatives regarding formulation of codes of conduct are mainly developed in a general and top down approach and do not account for the significance of regional variation in adoption and implementation.

In the scientific arena, sustainability of bioenergy has been an important research objective. In Blottnitz and Curran [9] several studies regarding environmental impacts of bioethanol production chains have been reviewed. In most of the studies, energy balances and greenhouse gas (GHG) balances of production chains have been assessed. In others, such as Kaltschmitt et al. [10], Lewandowski and Heinz [11] Hamelink and van de Broek [12], Malca and Freire [13], Blottnitz and Curran [9] and Styles and Jones [14] more complete Life Cycle Assessments (LCA) have been performed. Van den Broek et al. [15], Smeets et al. [16,17] Rowe et al. [18] and Börjesson $[19,20]$ are examples of studies on the sustainability of several bioenergy crops in specific countries that included a broad scope of environmental impacts and some even includes socioeconomic impacts. The national scope of these latter assessments implies a relative aggregated level of analysis without differentiating for region specific conditions. Physical and socio-economic conditions often vary strongly between and within regions and determine the design of bioenergy chains: the chains need to be physically feasible in the geographical region, but also need to be compatible with the socio-economic context. In addition, the interactions between the bioenergy chain and the regional conditions have a strong influence on the actual environmental and socioeconomic performance of bioenergy chains. A national approach could therefore give a distorted impression of the sustainability of bioenergy chains within regions. For that reason, the regional level is a more suitable level of analysis of the impact of biomass chains in order to safeguard sustainability of bioenergy chains for certification purposes. This is illustrated by van Dam [21] who made a region specific assessment of impacts of bioenergy production in the Pampa region in Argentina. Although this study took differences in physical context into account, the impacts were not assessed spatially explicit. Regional averages on physical parameters were used, e.g. for soil quality or water availability. As the spatial variation in determining parameters of impacts of biomass chains is significant, impacts would preferably assessed spatially explicitly.

The aim of this paper is to develop a methodological framework to assess the environmental impacts of regional biomass chains in a spatially explicit and integrated way. The production of ethanol from Miscanthus (Miscanthus $\times$ Giganteus) and sugar beet
(Beta vulgaris L.) in the North of the Netherlands (the province of Groningen, Friesland and Drenthe) is used as case study. The case area was selected because of the high data availability. This case study was also used to analyse the economic viability of regional biomass chains [22]. This study will explore the spatial variability of environmental impacts of bioenergy chains and builds on the previous analysis.

The environmental impacts identified by several (inter-) national initiatives regarding sustainability criteria of bioenergy production were used as a starting point for a selection of relevant impacts and suitable indicators, as these criteria reflect the areas of concern for large scale bioenergy application [23-25]. The environmental impacts taken into account in this study are: GHG emissions (both during lifecycle and due to land use changes), soil quantity and quality, water use and water quality, and biodiversity. The selection and adaptation of methodologies to assess the environmental impacts is based on an extensive literature review on impact assessments. In this study, it is assumed that there is no competition with food production as the land for bioenergy crops is limited to the arable land that could become available by means of more efficient agricultural production. The developments in land availability for bioenergy crops in the Netherlands is based on the study of de Wit et al. [26].

\section{Methods}

The level of spatial detail of the analysis depends on the availability and resolution of the required input data. For several impacts, a postal code area was selected as the level of spatial analysis. For other impacts, a grid level of $0.1-1 \mathrm{~km}^{2}$ was selected. Because of the heterogeneity of the criteria, it is neither possible nor appropriate to draw generic system boundaries and select a single functional unit. Therefore, system boundaries and functional units were decided on for every individual indicator.

In this study, it is assumed that only agricultural land (both arable land and pastures) is used for the cultivation of bioenergy crops. The effects of land use changes (LUC) for energy crop production were compared with the impacts of current agricultural land use. Nature areas were excluded beforehand. This is in line with the EU directive on the promotion of the use of energy from renewable sources [23]. The availability of agricultural land is therefore directly related to the intensification of agricultural land. As in the Netherlands the current state of agriculture is very advanced and consequently yield gaps are relatively small, only a small proportion of agricultural land is expected to become available for energy crops [22,26], Since current fertiliser and pesticide application levels in the Netherlands already meet legislative limits, it is assumed that the slight production growth of the remaining agricultural land are not a result of increased inputs but from improved management only. It is therefore assumed that this intensification will not result in significantly more environmental impact. Consequently, the environmental impacts related to the productivity increase of the remaining agricultural land were not included in 
this assessment. The impacts of cultivation of Miscanthus and sugar beet were assessed for the entire agricultural area. This allows a straightforward interpretation of the analysis and provides a rationale for the selection of most appropriate areas energy crop production.

Only potential direct effects of implementation of bioenergy chains were assessed. Second order effects and feedback loops, e.g. the effect of changes in nutrient leaching on biodiversity, are hard to quantify and to allocate and are due to their complexity, beyond the scope of this study. Indirect effects and displacement effects due to LUC were tackled beforehand by assuming that only surplus agricultural land could be dedicated to bioenergy crops. Based on the first order results of the assessment of the spatial variability of environmental impacts combined with results of the study on the spatial variation in economic viability of bioenergy chains [22], areas can be identified where bioenergy crop production is economically viable and have the least negative or possibly positive environmental impacts.

The environmental impact analysis of LUC to bioenergy crops on a spatially explicit and detailed level requires large amount of spatial data of soil characteristics, climate, current land use, yield, crop management, fertiliser and manure inputs and deposition levels, see, e.g. [16,21]. To deal with the large amounts of spatial data, a framework was developed to be able to calculate the impacts included in this study.

The Miterra model used in our study is derived from the MITERRA-Europe model, which was developed to assess the effects and interactions of policies and measures in agriculture on nitrogen (N) losses on a regional level in EU-27 [27]. Miterra simulates the $\mathrm{N}$ and phosphorous (P) balance, emissions of $\mathrm{NH}_{3}, \mathrm{~N}_{2} \mathrm{O}, \mathrm{NO}_{x}$, and $\mathrm{CH}_{4}$, leaching of $\mathrm{N}, \mathrm{NO}_{3}-$ concentration in groundwater and changes in soil and biomass carbon stocks at a postal code level. For the application in this study, the model was adapted and input data and parameter values were made region specific. The main input data of the model are crop areas and livestock numbers, which were derived from the Geographical Information system Agrarian Businesses database (GIAB) on postal code level. For the assessment of the impacts not included in the Miterra model, appropriate methods were selected and adapted for spatial explicit application. In the following sections, the methods used to asses every individual impact are discussed.

\subsection{GHG emissions}

One of the main drivers of bioenergy is the reduction of GHG emissions. Therefore, the GHG emission related to bioenergy production is an important indicator to take into account. The GHG emission of the bioenergy chains was calculated by combining the GHG emissions related to direct LUC and the GHG emissions during all stages of the ethanol production chain.

\subsubsection{GHG during life cycle}

GHG is emitted during the lifecycle of biofuels and is related to cultivation of the energy crop (diesel for agricultural machinery, seed pesticide and fertiliser production and fertiliser application), storage and transport (heat for drying, diesel for transport, dry matter loss) and processing (energy and chemical inputs for conversion process). The GHG emissions related to the production of bioenergy were calculated using a LCA approach which is often applied on bioenergy production chains. The ISO 14040-14049 guidelines articulate a preference for the use of system expansion in order to account for co products. As for legislative purposes energetic value based allocation is preferred in the EU directive on biofuels [28], this was applied in this study. The calculation of the GHG emissions was based on data provided by JEC [29] on the production of biofuels. For cultivation parameters, universal data were substituted by region specific data provided in van der Hilst et al. [22]. In Annex 1.1 , the data used to calculate the primary energy requirements and the GHG balances are depicted.

\subsubsection{GHG emissions due to LUC}

GHG emissions due to LUC are caused by changes in soil carbon stocks, above and below ground biomass and residues. When land is converted from one land use to another, carbon can accumulate (carbon sequestration) or diminish (carbon emissions). In addition, LUC causes changes in $\mathrm{N}_{2} \mathrm{O}$ emissions due to changes in fertiliser and manure application and drainage of organic soils. As it is assumed that there are no changes in livestock, livestock related $\mathrm{N}_{2} \mathrm{O}$ and methane emissions are assumed to remain constant when land is converted to energy crops. The Miterra model used here makes use of the methodology proposed in the IPCC guidelines to calculate the GHG emissions due to LUC [31]. In Annex 1.1, the parameters used to calculate changes in GHG emissions due to LUC are presented.

Direct $\mathrm{N}_{2} \mathrm{O}$ emissions from managed soils related to different $\mathrm{N}$ sources (manure, grazing, mineral fertiliser, crop residues and cultivation of organic soils) and indirect $\mathrm{N}_{2} \mathrm{O}$ emissions due to $\mathrm{N}$ leaching and $\mathrm{N}$ deposition were calculated by Miterra using emission factors of the IPCC guidelines [31,32]. The $\mathrm{N}$ surplus was calculated from the total $\mathrm{N}$ input (manure, mineral fertiliser, deposition and $\mathrm{N}$ fixation), the removal via crop harvesting and the $\mathrm{N}$ losses by gaseous emissions and runoff. Part of the $\mathrm{N}$ surplus is leached which results in direct $\mathrm{N}_{2} \mathrm{O}$ emissions [27]. In Annex 1.1 and 1.3 , the parameters to calculate the changes in $\mathrm{N}_{2} \mathrm{O}$ emissions are presented.

Due to lower nutrient requirements, less manure will be applied on herbaceous energy crops. As no change in manure production is assumed, a manure surplus could be developed. This potential manure surplus is not considered here as it is outside the scope of this study. The annual changes in SOC, the change in carbon flux from organic soils and the changes in annual $\mathrm{N}_{2} \mathrm{O}$ emissions were combined to calculate the changes in annual GHG emission.

\subsection{Soil quality}

As soil quality is a broad and wide-ranging concept, it was narrowed down to indicators that are relevant for the region and for measuring the effect of bioenergy crop production on the soil. Soil organic matter (SOM) and soil erosion hazard are the indicators of soil quality that were selected in this study in line with the studies of Smeets et al. [33] and van Dam et al. [21,34].

\subsubsection{Soil organic carbon}

As the SOC content is closely related to the amount of SOM, SOC is used as a proxy indicator. In addition to the benefits of carbon sequestration in the soil (see Section 2.1.2), SOC is also linked to other important functions of the soil like water holding capacity, nutrient retention and soil structure $[18,35]$. SOC is therefore considered to be the most prominent indicator for soil quality [36].

SOC is affected by soil type, climate, past and present land use, soil and water management [37]. In the Netherlands, most soils have a high SOC content. Pastures usually contain more SOC than arable land due to continuous land cover, higher root biomass, high animal manure application rates and absence of tillage. Sandy soils have generally lower organic matter content than clay soils because of higher organic decomposition rates [37]. As wet conditions slow down decomposition rate, soils with high water tables contain generally more SOC [37]. Peat lands store the largest amount of SOC but annual losses due to cultivation and drainage are high [37]. Changes in SOC were evaluated for the LUC related GHG. The methodology applied is discussed in Section 2.1.2. 
Table 1

parameters of the WEQ equation.

\begin{tabular}{|c|c|c|c|c|c|}
\hline \multicolumn{3}{|c|}{ Parameter } & \multirow{2}{*}{$\begin{array}{l}\text { Unit } \\
\text { ton ha }{ }^{-1} \mathrm{y}\end{array}$} & \multirow[t]{2}{*}{ See Annex } & \multirow[t]{2}{*}{ Ref. } \\
\hline$E$ & Erosion & Potential average annual soil loss & & & \\
\hline$I$ & Soil erodibility index & $\begin{array}{l}\text { The potential annual soil loss per hectare for an open unsheltered } \\
\text { isolated levelled field with a smooth bare crustless surface. Related to } \\
\text { texture, organic matter, calcium carbonate concentration }\end{array}$ & ton ha $\mathrm{a}^{-1} \mathrm{y}$ & Table A1.3 & $\mathrm{a}, \mathrm{b}$ \\
\hline$K$ & Soil surface roughness factor & $\begin{array}{l}\text { Reduction of the potential wind erosion due to ridges of the soil. } \\
\text { Related to ridges and cloddiness made by field operations }\end{array}$ & factor & Table A1.5 & b \\
\hline$C$ & Climate factor & $\begin{array}{l}\text { Local climatic erosivity. Related to wind speed, precipitation and } \\
\text { temperature }\end{array}$ & factor & Table A1.4 & c \\
\hline$L$ & Length of field & Unsheltered distance across a field along the prevailing wind direction & $\mathrm{m}$ & & \\
\hline$V$ & Vegetation factor & $\begin{array}{l}\text { Equivalent vegetative cover. Kind, amount and orientation of the } \\
\text { vegetation expressed in Small Grain equivalents (SGe) }\end{array}$ & ton ha $\mathrm{a}^{-1} \mathrm{y}$ & Table A1.5 & d \\
\hline
\end{tabular}

\footnotetext{
a USDA et al. (2002).

b van Kerckhoven et al. (2009).

c Heijboer et al. (2002).

d NRCS (2006).
}

\subsubsection{Soil erosion}

In areas prone to soil erosion, LUC may have a significant effect on the actual erosion risk. The main on-site problem caused by erosion on agricultural land is the loss of fertile top soil which leads to degradation of arable soils [37-40] and crop damage caused by abrasion or burial of seedlings or plants and the exposure and loss of seed [41]. In addition, the transport of minerals, organic matter, residues and pesticides could cause contamination of surrounding surface water $[39,42]$. Furthermore, airborne particles due to wind erosion could affect human and animal health, machinery and infrastructure $[39,40]$. The main factors determining the actual erosion risk, are the soil characteristics (especially soil moisture and soil structure), vegetation (soil cover) and slope (in case of water erosion) $[37,38]$. It is therefore important to assess the effect of LUC or farm management on these factors in regions with high erodible soils and periods with high erosive rainfall or wind.

Most studies regarding erosion focus on erosion caused by water, as this is the dominant form of erosion in most areas [38]. In the Netherlands, soil erosion due to runoff is mainly occurring in the sloping areas in the South-East $[37,43]$. The erosion hazard map of the Netherlands by Eppink and Spaan [43] shows no erosion risk due to rainfall runoff in the North of the Netherlands as this area has an outspoken flat morphology and the soils have a relatively high infiltration capacity. For this reason, rainfall related erosion is not included in this study. Wind erosion, however, does play a role in this region. Areas underlain by sandy and reclaimed cut-over peaty soils with frequent tillage on large fields without barriers are susceptible to wind erosion $[37,40,43,44]$. It is estimated that the vulnerable area of wind erosion in the in the North Netherlands amounts up to 60 kha.

Several methods have been developed to model wind erosion for different temporal and spatial scales, functionalities (specific circumstances) and impacts (soil loss, particle concentration). Ideally, soil erosion is continuously measured in the field or estimated by very exact wind erosion models fed with continues data on physical parameters. However, this is very time and capital intensive. In this study, the wind erosion equation (WEQ) method is applied. This is a relatively simple methods that requires less detailed input data and can be applied on a regional level as demonstrated by Van Kerckhoven [42]. The WEQ estimates the average soil loss due to wind erosion (in ton ha $\mathrm{a}^{-1} \mathrm{y}^{-1}$ ). Eq. (1) and Table 1, give the parameters of the WEQ derived from USDA and NRCS [40], Morgen [45] and van Kerckhoven [42]. The complex relations between the parameters and the input data to calculate the soil loss are explained in Annex 1.2 .

$E=\int(\mathrm{IKVCL})$
When land is converted from conventional use to bioenergy crops, most factors included in the WEQ remain constant. The soil surface roughness factor could change slightly $( \pm 20 \%)$ due to modifications in tillage and planting practices. The main factor that will change is the equivalent vegetative cover. The erosion risk is determined for every individual crop for every month of the year. To calculate the erosion risk for rotations, the risk of the rotation crops are combined in a weighted summation based on the portions of the crops in the rotation. For grass, it is assumed that pastures are reseeded every 10 years. For Miscanthus a lifetime of 20 years is assumed (1 year of establishment, 19 years of full crop cover, early spring harvesting). All parameters used for the calculations of wind erosion are depicted in Annex 1.2. In line with the WEQ guidelines, the most critical month has been selected based on calculations (see Fig. A2.3 and A2.4 Annex).

\subsection{Water quantity and water quality}

Water use and water quality are often addressed in proposed sustainability criteria for bioenergy $[3,24,46]$. As a relatively small proportion of the total water consumption for biofuel production is used during the processing stage $(<10 \%)[47-50]$, only the water use related to crop production is taken into account. The assessment of the impact on water quality is limited to evaluation of the effect of change in use of agrochemicals like fertilisers on the water quality.

\subsubsection{Water use}

The change from current land use to energy crops may change the water balance of an area due to changes in evapotranspiration, runoff and percolation [33]. The amount of water lost through evapotranspiration depends on crop type, growth stage, climate, soil characteristics growing period and agronomic practice [48,50-52]. As in the North of the Netherlands only a minor proportion of the agricultural land is irrigated (1\% in wet years to $11 \%$ in dry years [53]), water withdrawal for irrigation is not incorporated in this study.

Preferably, the impact of energy crops on fresh water availability for other functions is assessed on a water basin level [50]. This approach however, requires detailed knowledge and data about the hydrologic flows within a specific water basin. In this study, the changes in the water balance when current land use is converted to bioenergy crops was assessed on a spatial level of $1 \mathrm{~km}^{2}$ grids. In addition, a comparison was made between the region specific water use efficiency (WUE) of the two bioenergy crops.

To assess the potential water depletion due to the introduction of bioenergy crops, a simple water balance was made by comparing the evapotranspiration to the effective precipitation like done in the studies of Smeets and Faaij [17] and van Dam et al. [21] (see 
equation in Appendix A1.3). The calculation method of water depletion is made time and spatially explicit by making use of spatial data on long term averages of monthly precipitation $\left(1 \mathrm{~km}^{2}\right)$ of the Royal Netherlands institute for Meteorology (KNMI). The effective precipitation (EP) is defined as the rainfall that is useful or usable in any phase of the crop production [54] and is derived from the actual rainfall making use of the USDA formula in the CROPWAT 8.0 model [55]. The spatial distribution of monthly reference evapotranspiration $\left(\mathrm{ET}_{0}\right)$ was constructed on a $0.1 \mathrm{~km}^{2}$ grid level for the North of the Netherlands by means of aggregation and spatial interpolation of daily $\mathrm{ET}_{0}$ data of the KNMI weather stations in the region. Although the Penman-Monteith equation is the most widely applied method to calculate $\mathrm{ET}_{0}$, the KNMI uses the Makkin method for practical reasons [56,57].

The crop evapotranspiration coefficients (Kc factors) mainly depend on crop type, growth stage of crop and climate [58]. The crop specific decadal Kc factors for the Dutch situation were derived from the KNMI [59]. The spatial $0.1 \mathrm{~km}^{2}$ grid maps of monthly $\mathrm{ET}_{0}$ were converted to land use specific monthly evapotranspiration maps, using the crop specific monthly Kc factors. The average monthly evapotranspiration of rotations were calculated using a weighted summation of the individual crops.

As water deficits only occur during the summer in this area [59], the assessment of the change in total water deficit focussed on the months April-August. The parameters used for the calculation of the spatially explicit water deficit are depicted in Annex 1.3.

The Water Use Efficiency (WUE) indicator is frequently applied in bioenergy related studies, like in Berndes et al. [48], Dornburg et al. [50], van Dam et al. [21], Fraiture and Berndes [47] and Smeets and Faaij [17]. In this study, the WUE is used as a second indicator of water consumption. It provides an indication about the water requirements per unit crop produced, whereas the water deficit methodology only provides figures for water use per hectare. In order to assess the spatial explicit WUE of bioenergy crops, knowledge on water availability (precipitation and ground water) and the effect of different growth limitation factors on evapotranspiration rates should be considered. As here are too many uncertainties in these parameters, only a regional average WUE was calculated.

\subsubsection{Water quality}

The use of agricultural chemicals like pesticides and fertilisers may contaminate ground and surface water. A change in the use of these chemicals due to LUC in favour of energy crops is expected to have impact on the water quality. In this study, we focused on contamination of water due to fertiliser and manure use only, as these cause the most persistent problems in The Netherlands. An oversupply of $\mathrm{N}$ is likely to cause leaching of $\mathrm{N}$ to ground and surface water. The $\mathrm{N}$ surplus was calculated in the Miterra model as described in introduction section of the methods. Part of the surplus is denitrified and part will leach the ground and surface water. The amount of $\mathrm{N}$ leaching was calculated by multiplying the $\mathrm{N}$ surplus by a leaching fraction, which was based on the soil type, land use and groundwater level [60]. The $\mathrm{NO}_{3}{ }^{-}$concentration in ground water was calculated by dividing the $\mathrm{N}$ leaching flux by the precipitation surplus. For $\mathrm{P}$ there is no direct relation between the $P$ accumulation in the soil and the concentration in ground and surface water. However, when $\mathrm{P}$ application levels exceed the $\mathrm{P}$ removal by crop uptake over longer periods of time, the risk of $\mathrm{P}$ leaching to water will increase. The $\mathrm{P}$ balance is calculated by Miterra making use of data on P inputs (manure, grazing, mineral fertiliser application and deposition) and P uptake by crops [32]. The input data required for the calculations of changes in $\mathrm{NO}_{3}{ }^{-}$concentration in groundwater and change in $\mathrm{P}$ balances are included in Annex 1.3.

\subsection{Biodiversity}

In most of the developed sustainability criteria for bioenergy, impacts on biodiversity have been identified as an important area of concern. LUC is a strong driver of changes in biodiversity [61-64]. Because of the loss, modification and fragmentation of habitats, the (indirect) expansion of agricultural land for energy crop production is perceived to be a major threat for biodiversity [65]. Biodiversity is also affected by LUC related depletion, degradation and pollution of ecosystems and invasive species $[64,66]$. Changes in habitats due to energy crop production are most significant when natural areas are converted to (intensive) agriculture areas [67]. Most bioenergy sustainability criteria deal with this issue by proposing process indicators, e.g. by referring to national regulations and by excluding protected areas and land identified as area with high biodiversity from bioenergy production [28]. In this study, these areas are excluded beforehand and only changes in agricultural land use are assessed. Currently, few guidelines are available about quantitative result indicators and methods to assess the impacts of energy crop production on biodiversity [46]. This is especially true for assessing agro-biodiversity on a regional level.

Over the last decades, several indicator systems have been developed to assess changes in biodiversity. These indicator systems vary to a great extent according to scale (global, national, regional or local), purpose (policy targets), and focal area of biodiversity (species, genetic variation, population size or ecosystems). The impact of energy crop cultivation on biodiversity depends on both local scale effects (choice of crop, management intensity, vegetation structure, substituted land use) and landscape scale effects (geographical location, scale and distribution of crops) [68]. The objective in this study is to quantify the impact of bioenergy crop production on agro-biodiversity on a local scale and identify the areas with a high risk on biodiversity loss. Two indicator systems, the High Nature Value (HNV) and the Mean Species Abundance (MSA) were selected for this assessment.

HNV has become one of the main indicators to assess the impact on biodiversity of the 2007-2013 Rural Development Programs [69] and for the integration of environmental concerns into the Common Agricultural Policy [67]. High Nature Value (HNV) farmland are certain types of farmland that, because of their characteristics, can be expected to support high levels of biodiversity of conservation concern [69]. JRC and EEA developed a method to identify HNV farmland [70]. Elbersen and van Eupen [71] adapted the HNV method for the Netherlands based on more detailed spatial data on HNV parameters. The HNV indicators used in this study are explained in Annex 1.4. Based on the characteristics of the HNV types and characteristics of the energy crops, the impact of a shift to bioenergy crop production on biodiversity in a HNV area was qualitatively assessed on a detailed geographical level. The risk level of biodiversity loss was identified based on the extent to which the new land use function could meet the habitat functions requirements of the important species identified by the HNV cluster indicators (see Table A1.9). The areas where the implementation of Miscanthus or sugar beet could cause a 'high risk of biodiversity loss', 'considerable risk of a biodiversity loss' and 'both positive and negative effects on biodiversity' were mapped. The HNV approach does not provide information about the impact of a shift towards bioenergy crops on biodiversity outside the HNV areas. In addition, the HNV approach does not measure the change in biodiversity quantitatively.

The Mean Species Abundance (MSA) is a quantitative indicator for change in biodiversity. It does not reflect individual species responses but represents the average response of the total set of original species relative to their abundance in undisturbed ecosystems [72]. This indicator does not cover all aspects of the complex concept of biodiversity, but it can be used appropriately 


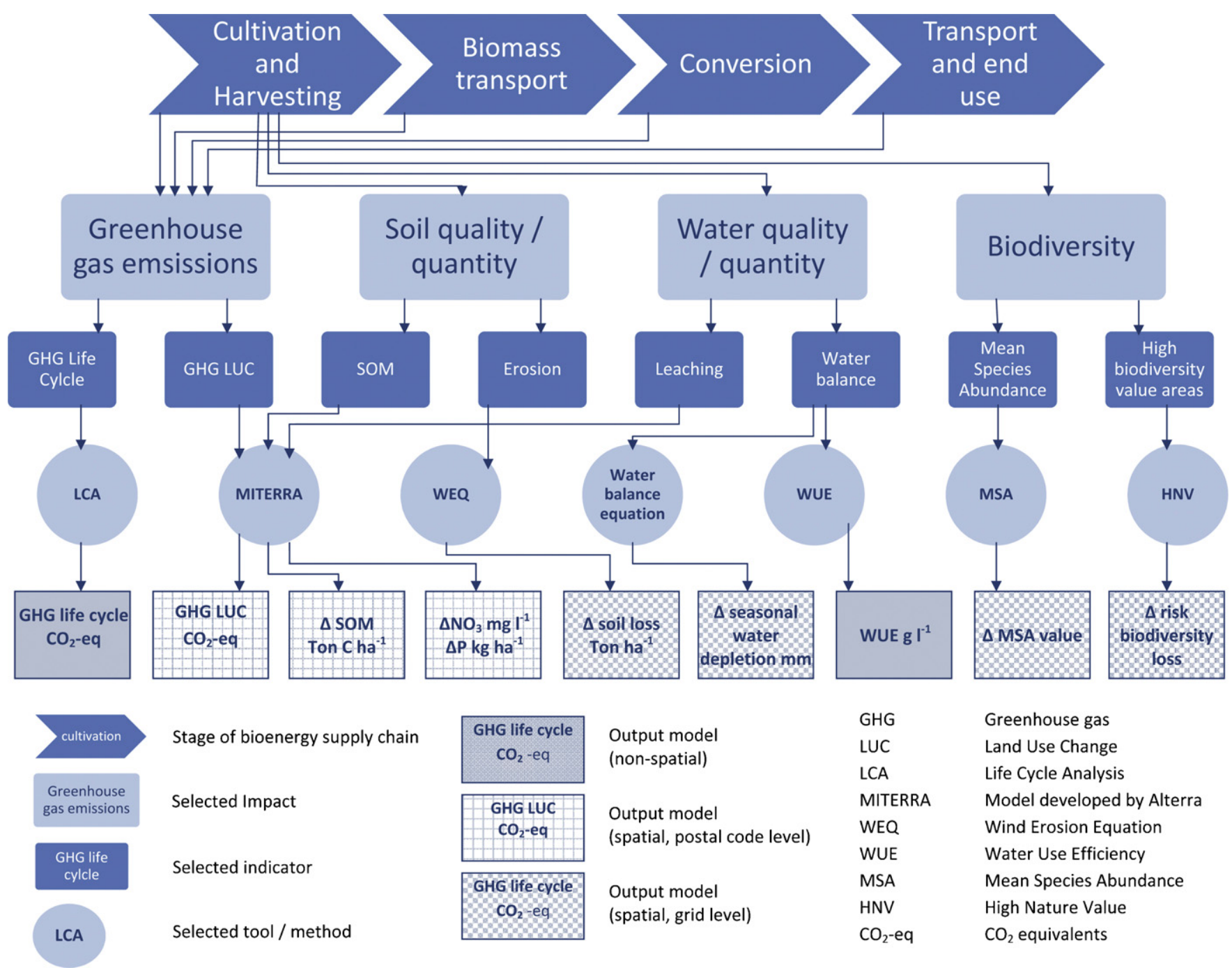

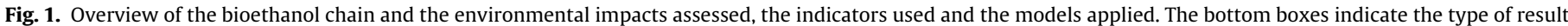
that is generated from the assessments.

to assess changes in biodiversity due to changes in land use for bioenergy crops. It was successfully applied in several global en regional studies concerning changes in biodiversity [50,73,74]. The MSA values for several land cover types are (included in Table A1.10 of the Annex) was linked to a map of current land use. However, as this land use map does not account for diversity within a land use type, management practices or locally available biodiversity, the MSA provides little differentiation for agricultural land in the Netherlands. For all areas outside the HNV areas, the MSA indicator is applied to assess the impact of LUC to bioenergy crops on biodiversity.

\subsection{Overview methods and integration of results}

Fig. 1 shows an overview of the bioenergy supply chain, the impacts that are assessed, the methods that are applied and the type of results that are produced in this study.

For an integral picture, the GIS maps layers of the potential environmental impacts have been combined. As all impacts are measured in different units and scales, combining impacts requires standardisation of the GIS map layers. For all indicators, maximum standardisation was applied in which all negative impacts were translated to a scale from 0 to -10 and all positive effects to a value between 0 and +10 . In this standardisation process, impacts equal to the impact of current land use were set to ' 0 ', all increases in impacts compared to current land use were assumed to be negative and all decreases in impacts were assumed to be positive. In order to prevent a skewed distribution in standardised values due to extreme results of the indicators, the maxima were set on 2 times the standard deviation from the average. In order to compare the results of Miscanthus and sugar beet, the same standardisation has been applied for the results of both crops. In this integrated assessment, it is assumed that all environmental impacts are equally important.

\section{Results}

\subsection{GHG during lifecycle}

The GHG emissions over the production chain of bioethanol are substantial (see Fig. 2). The results found in this assessment are comparable with the figures found in previous studies [75-78] Bioethanol production of Miscanthus causes fewer GHG emissions than first generation biofuels. As thermal energy requirements for 2nd generation conversion are assumed to be fuelled by part of the feedstock, the process requires less fossil energy. Fig. 2 shows the relative importance of GHG emissions due to changes in SOC compared to the emission during the lifecycle. The uncertainty bars indicate the spatial variation in SOC change for a 20 year period. As 


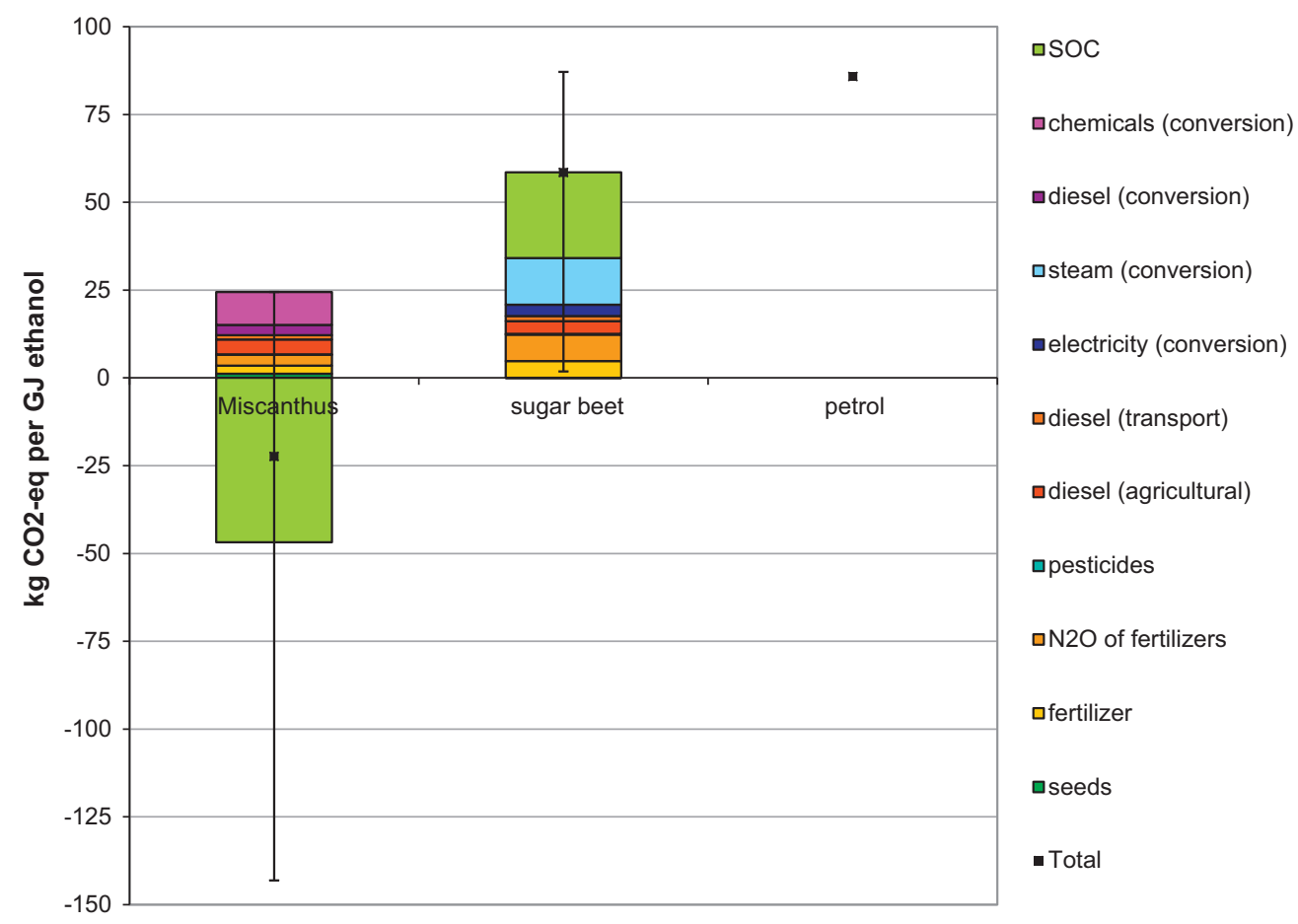

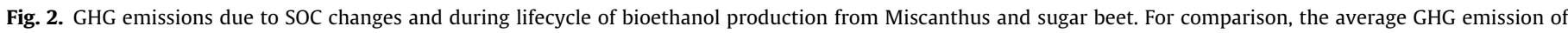
petrol over the lifecycle is depicted.

the emission reduction potential of a bioenergy production chain is highly related to the location of production this needs to be spatially assessed (see Fig. 3).

\subsection{GHG emissions due to LUC}

Fig. 4 shows the changes in GHG emissions due to LUC from current land use to Miscanthus and sugar beet. This includes the changes in carbon stocks (Fig. 3), the changes in carbon fluxes from organic soils and $\mathrm{N}_{2} \mathrm{O}$ emissions (Fig. A2.2 Annex).

When grassland is converted to Miscanthus, a carbon loss due to land clearing (biomass carbon, up to 5.4 ton $\mathrm{Cha}^{-1}$ ) and soil preparation prior to Miscanthus planting (soil carbon, 1 ton $\mathrm{Cha}^{-1}$ on sandy soils, 2.5 ton $\mathrm{Cha}^{-1}$ on clay soils) is compensated by relatively large above and below ground biomass stock (up to 17.5 ton $\mathrm{Cha}^{-1}$ ) that Miscanthus achieves compared to grass. When cropland is converted to Miscanthus, relatively large amounts of carbon are sequestered both in biomass and soil carbon ( 8.5 ton $\mathrm{Cha}^{-1}$ on sandy soils, 21.5 ton ha ${ }^{-1}$ on clay soils). For Miscanthus, the GHG emission reduction through carbon sequestration varies between 0 to $-78 \mathrm{~kg} \mathrm{GJ}_{\text {ethanol }}{ }^{-1}$. For sugar beet, the GHG emissions due to changes in carbon stocks vary between 0 and $54 \mathrm{~kg} \mathrm{GJ}_{\text {ethanol }}{ }^{-1}$. These figures are in line with the studies of Foereid et al. [79] and Schneckenberger and Kuzakov [80] on sequestration potential of Miscanthus and with the study of Kuikman [35] on SOC in the Netherlands.

LUC related $\mathrm{N}_{2} \mathrm{O}$ emissions contribute significantly to the GHG emissions. Conversion of current land use to Miscanthus generally decreases $\mathrm{N}_{2} \mathrm{O}$ emissions. Especially when pastures (generally high fertiliser and manure application levels) are converted to Miscanthus, $\mathrm{N}_{2} \mathrm{O}$ emissions decrease significantly $\left( \pm 1.7\right.$ ton $\mathrm{CO}_{2}$ eq $\mathrm{ha}^{-1} \mathrm{y}^{-1}$ ). For Miscanthus, the GHG emission reduction though LUC related $\mathrm{N}_{2} \mathrm{O}$ emission reduction varies between 0 and $-21 \mathrm{~kg}$ $\mathrm{CO}_{2}$ eq $\mathrm{GJ}_{\text {ethanol }}{ }^{-1}$. LUC to sugar beet cause an increase of $\mathrm{N}_{2} \mathrm{O}$ emissions in almost all areas, with highest increases on arable land. This is mainly caused by the higher fertiliser application levels and the increased emissions from crop residues (sugar beet leaves and crowns). For sugar beet ethanol, the LUC related $\mathrm{N}_{2} \mathrm{O}$ emissions contribute $0-15 \mathrm{~kg} \mathrm{GJ}_{\text {ethanol }}{ }^{-1}$ to the GHG balance (see Fig. A2.2 Annex).

Because LUC could cause an increase in one type of GHG but a decrease in another GHG, changes could balance each other out (for example: leaving the residues of sugar beet on the field will increase SOC but it will also increase $\mathrm{N}_{2} \mathrm{O}$ emissions from residues). In general, LUC towards Miscanthus will reduce GHG emissions, especially conversion of arable land. LUC to sugar beet will generally cause a net increase in GHG emissions. The amount of GHG emissions is relatively high in areas now in use for pastures. For Miscanthus, the GHG emission reduction compared to current land use varies between 0 to $-159 \mathrm{~kg} \mathrm{CO}_{2}$-eq $\mathrm{GJ}_{\text {ethanol }}{ }^{-1}$ ( -15 ton $\mathrm{CO}_{2}$ eq $\mathrm{ha}^{-1}$ ). When arable land is converted to sugar beet, relatively small changes in GHG emissions occur. The GHG emissions due to LUC to sugar beet range from 0 to $148 \mathrm{~kg} \mathrm{GJ}_{\text {ethanol }}{ }^{-1}$ ( -1 ton $\mathrm{CO}_{2}$ eq ha ${ }^{-1}$ ).

\subsection{Soil erosion}

The risk on erosion (in ton ha $\mathrm{y}^{-1}$ ) for current land use is shown in Fig. A2.5 in the Annex and the changes in the risk on erosion due to LUC are depicted in Fig. 5. The figures are based on the parameters for April which is the most sensitive period of the year for wind erosion due to low crop coverage, decreased soil moisture levels and relatively high wind velocities (See Annex 2.2).

Although the overall risk on erosion is relatively small (max $<6$ ton ha $\mathrm{y}^{-1}$ ), this could still have severe negative effects. In the current situation, light sandy soils in the south east of the region (veenkoloniën) are the areas most at risk for soil erosion. In the areas prone to soil erosion, relative large changes in erosion risk occur. When arable land is converted to Miscanthus, erosion risk is significantly reduced. Although it is assumed that grass is renewed every 10 years and Miscanthus every 20 years, risk on erosion increases when pastures are converted to Miscanthus. This is related to the planting date of grass which is generally seeded in 

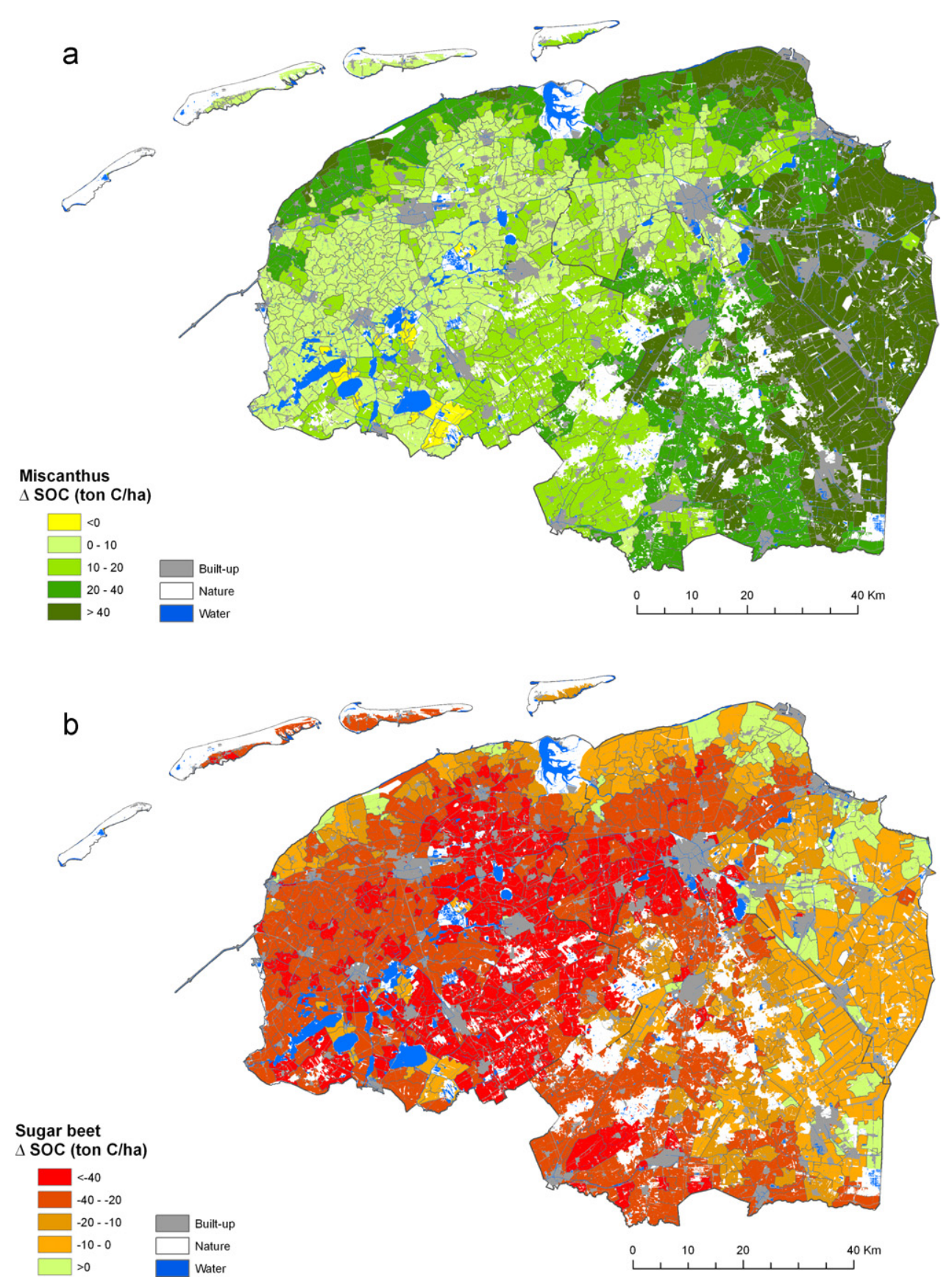

Fig. 3. (a) $\Delta$ SOC when current land use is converted to Miscanthus. (b) $\Delta$ SOC when current land use is converted to sugar beet.

September. By the time the soil gets prone to erosion in spring, grass already covers the soil to a large extent. Miscanthus, however, needs to be planted in spring and has a slow crop development in the initial growth stage. Therefore, in the year of establishment the risk on erosion is relatively high. These findings are in line with Kort et al. [81]. The risk on erosion increases up to 3 ton ha ${ }^{-1} y^{-1}$ when sugar beet replaces crop rotations. When sugar beet replaces pastures, the risk on erosion can even increase up to 9 ton ha- $\mathrm{y}^{-1}$ on sandy soils.

\subsection{Water}

\subsubsection{Water consumption}

In the current situation, evapotranspiration of crop rotation and pasture land exceed the effective precipitation in the months
April to September (see Fig. A2.6 of the Annex). Therefore, a cumulative deficiency occurs during these months. As the effective precipitation exceeds the evapotranspiration considerably during the rest of the year, all water shortages are eventually replenished. However, temporary shortages during the summer could cause damages to agricultural production or natural areas. The evapotranspiration of Miscanthus exceeds the evapotranspiration of both pastures and rotations of arable crops from May to September. During July and August the evapotranspiration of sugar beet exceeds the average evapotranspiration of rotations and pastures. Therefore, LUC to bioenergy crops could cause higher water consumption rates during summer. As water tables are regulated artificially in the Netherlands, more water should be supplied to the areas with higher water requirements. The developments in crop specific evapotranspiration 

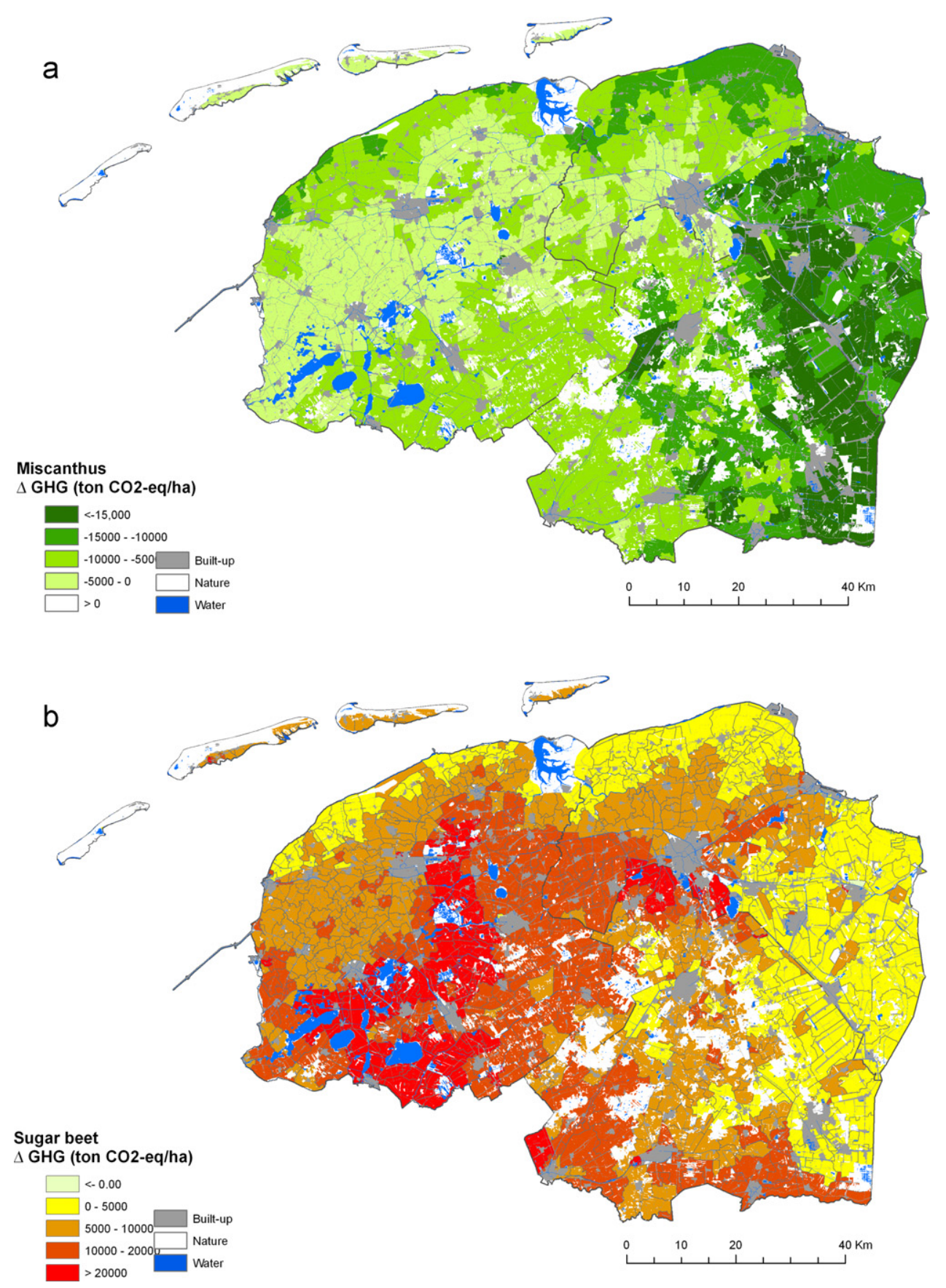

Fig. 4. (a) $\Delta$ GHG when current land use is converted to Miscanthus. (b) $\Delta$ GHG when current land use is converted to sugar beet.

over time in relation to the effective precipitation is depicted in Fig. A2.6 of the Annex.

The spatial variation in water deficits during the months April-August caused by evapotranspiration of current land use is depicted in Fig. A2.7 of the Annex. The largest water shortages occur in the western part, as precipitation is relatively low in this area compared to the rest of the region. The change in water shortages when current land use is converted to Miscanthus, are depicted in Fig. 6a. The spatial variation in change in water deficits due to the introduction of sugar beet is depicted in Fig. $6 \mathrm{~b}$.

In addition to the spatial water balance, the regional WUE was measured. In Fig. A2.8 of the Annex, the WUE for Miscanthus and sugar beet is depicted. Most studies indicate that the WUE of C4 crops is generally higher than the WUE of C 3 crops $[48,50]$. However in this study, it was found that the WUE of Miscanthus $\left(2.23 \mathrm{~g} \mathrm{~kg}^{-1}\right.$ water) is lower that for sugar beet $\left(3.87 \mathrm{~g} \mathrm{~kg}^{-1}\right.$ water). This can be explained by the fact that the competitive advantage of the $\mathrm{C} 4$ photosynthesis pathway decreases significantly further away from the equator. In addition, as climatic conditions and agricultural management are optimal for sugar beet production, it achieves relatively high WUE. The WUE found for Miscanthus is in line with the $2.1 \mathrm{~g} \mathrm{~kg}^{-1}$ found by Clifton Brown [82] and the range of 1-9.5 $\mathrm{g} \mathrm{kg}^{-1}$ provided by Berndes [48]. The regional WUE of sugar beet is in line with the range of $2.55-3.83 \mathrm{~g} \mathrm{~kg}^{-1}$ given by [50].

\subsubsection{Water quality}

The Miterra model was used to calculate the nitrogen and phosphorous balance in the soil. Based on the $\mathrm{N}$ balance and the water 

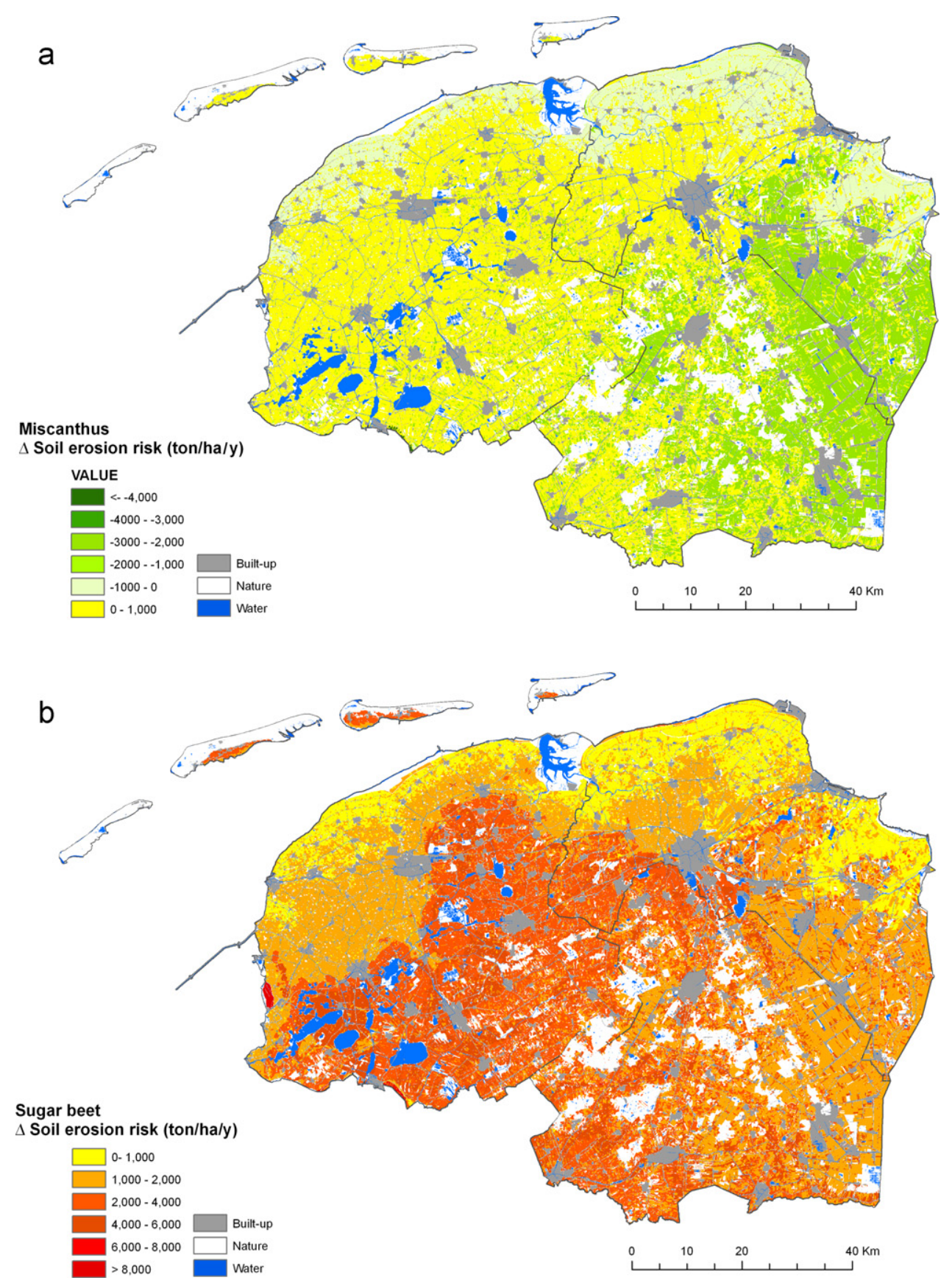

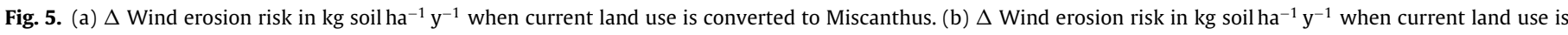
converted to sugar beet.

surplus, the $\mathrm{NO}_{3}{ }^{-}$concentration in the ground water was calculated. The maps of the $\mathrm{N}$ and $\mathrm{P}$ balance are included in Annex 2.3. As $\mathrm{N}$ and $\mathrm{P}$ fertiliser application levels are closely linked, the spatial patterns of changes in $\mathrm{N}$ and $\mathrm{P}$ balances are quite similar. Because of the large differences between the current fertiliser and manure input on pasture and the fertiliser requirements of Miscanthus, the $\mathrm{N}$ and $\mathrm{P}$ surplus will be significantly reduced when pasture area is converted to Miscanthus. Also in the areas where sugar beet substitutes grassland $\mathrm{N}$ and $\mathrm{P}$ surpluses are reduced. However, when sugar beet substitutes a rotation of crops, $\mathrm{N}$ and $\mathrm{P}$ surpluses increase. The high increases of $\mathrm{N}$ and $\mathrm{P}$ occur when rotations with high proportions of cereals are converted to sugar beet. This is mainly caused by the relatively high fertiliser application rates of sugar beet compared to other rotation crops.
The differences in patterns between the $\mathrm{N}$ balance and $\mathrm{NO}_{3}{ }^{-}$ concentrations can be explained by the differences in leaching rates (lower for grassland, peat soils and lower precipitation surpluses). The $\mathrm{NO}_{3}{ }^{-}$concentration in $\mathrm{mg} \mathrm{NO} \mathrm{N}^{-1}$ is shown in Fig. 7. The current $\mathrm{NO}_{3}{ }^{-}$levels are $72 \mathrm{mg} \mathrm{l}^{-1}$ on average and $75 \%$ of the zip code districts exceed the standards of $50 \mathrm{~g} \mathrm{l}^{-1}$ of the Nitrate directive [83]. In general, the $\mathrm{NO}_{3}{ }^{-}$concentration decreases when current land use is converted to Miscanthus. The average change in $\mathrm{NO}_{3}{ }^{-}$ concentrations is $-53 \mathrm{mg} \mathrm{l}^{-1}$ and varies between 0 in areas with a large fraction of arable land and $-187 \mathrm{mg} \mathrm{l}^{-1}$ in zip code areas with a high proportion of grassland. When pasture area is converted to sugar beet, a decrease in $\mathrm{NO}_{3}{ }^{-}$concentration (of max $-75 \mathrm{mgl}^{-1}$ ) occurs. When arable land is converted to sugar beet, an average increase in $\mathrm{NO}_{3}{ }^{-}$concentrations of $16.5 \mathrm{mg} \mathrm{l}^{-1}$ is simulated. 

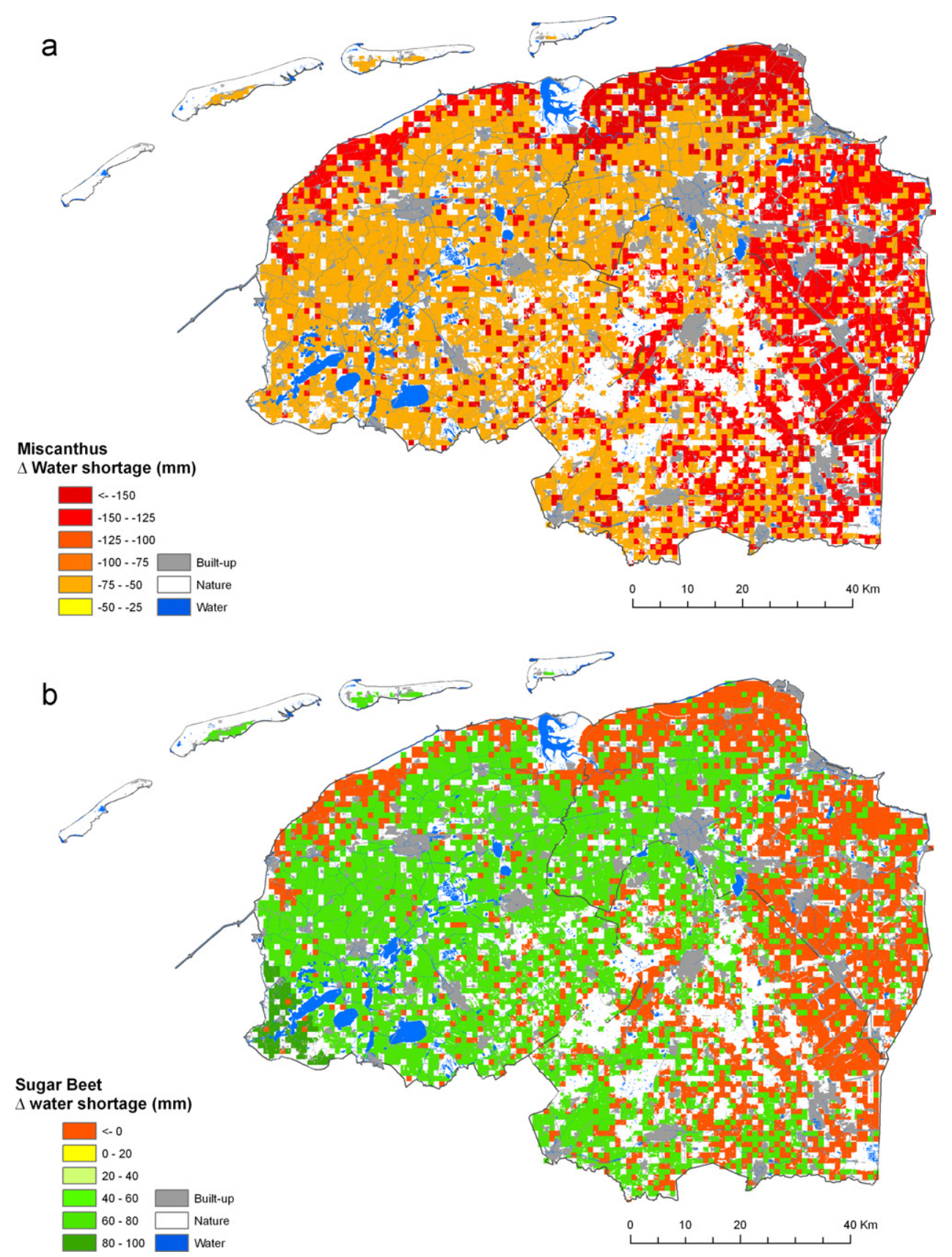

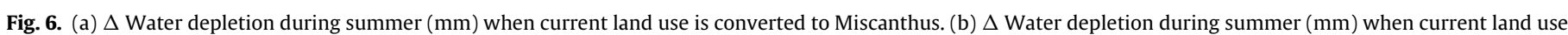
is converted to sugar beet.

\subsection{Biodiversity}

In Fig. 8, the HNV areas were biodiversity is at risk when current land use is converted to bioenergy crops are mapped. It shows that in almost the entire pasture area in the north of the Netherlands which comprises high densities of important species (endangered bird species and large shares of European populations of meadow and/or wintering birds), biodiversity is at risk when current land use is converted to either Miscanthus or sugar beet.

The HNV areas where biodiversity is at risk when converted to sugar beet $\left(532 \times 10^{3}\right.$ ha, of which $193 \times 10^{3}$ ha at 'high risk') are more extensive than for conversion to Miscanthus (473 $10^{3}$ ha, of which $91 \times 10^{3}$ ha at 'high risk'). The areas where LUC to bioenergy crops is expected to cause a considerable risk of biodiversity loss, are considered to be areas where energy crops should be introduced with care. The areas with a high risk on biodiversity loss are considered to be no-go areas for bioenergy crops. In some areas $\left(59 \times 10^{3} \mathrm{ha}\right)$ the introduction of Miscanthus could have both a positive and a negative effect on biodiversity. These are mainly the heterogeneous areas and the extensive managed arable areas in the east of the region.

For the areas not included in the HNV areas, the change in biodiversity is expressed in the change in MSA value. This mapped in Fig. A1.11a and $b$ of the Annex. The change in MSA value indicates an increase in biodiversity when pasture land is converted to Miscanthus and especially when arable land is converted to Miscanthus. The MSA values indicate a decrease in biodiversity when pasture land is converted to sugar beet cultivation and a status quo in biodiversity when sugar beet is cultivated in arable areas. The results show that sugar beet will induce a risk of biodiversity loss both 

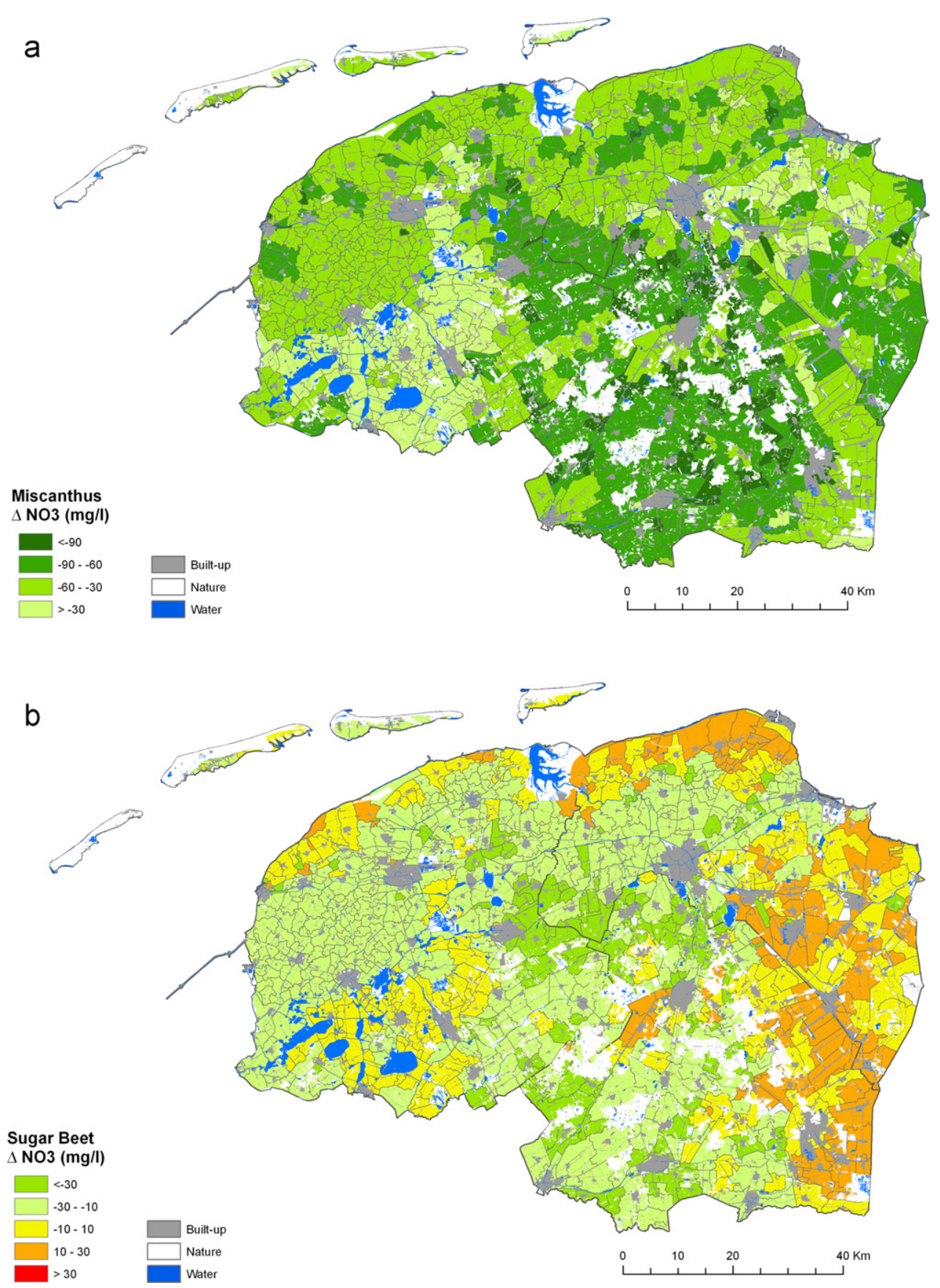

Fig. 7. (a) $\Delta \mathrm{NO}_{3}{ }^{-}$concentration when current land is converted to Miscanthus. (b) $\Delta \mathrm{NO}_{3}{ }^{-}$concentration when current land is converted to sugar beet.

within and outside the HNV areas and that the only areas where no negative effects on biodiversity occur are the areas already in use for intensively managed arable crops.

\subsection{Integrated results}

In Fig. 9a and b the integrated results of all environmental impacts are spatially depicted for both Miscanthus and sugar beet. The results are expressed as an average score on a standardised scale from -10 to +10 . In general, Miscanthus has better overall scores (mean $=2.33$ ) than sugar beet $($ mean $=-0.85)$. The results discussed in previous sections show a wide distribution of scores for the individual impacts. As the integrated results show average scores close to 0 , it illustrates that there are several trade-offs between impacts and that positive and negative scores balance each other out to some extent.

There are no areas where only positive impacts occur when current land use is changed to sugar beet or Miscanthus. For both crops, the western wet pasture area and the peaty south east area of Drenthe appear to be the areas with most negative impacts. The conversion of pasture land to arable crops on (reclaimed) peat areas has negative impact on carbon stocks, risk on erosion and biodiversity. These negative impacts are relatively small for Miscanthus but quite severe for sugar beet. The impacts in these areas would even be more severe in case the pasture areas were not as intensively managed as they are today. Sugar beet has also a negative environmental performance in the eastern part of the region. This area is characterised by arable land on sandy soils. As sugar beet is a more intensively managed crop than average arable crop rotations, 

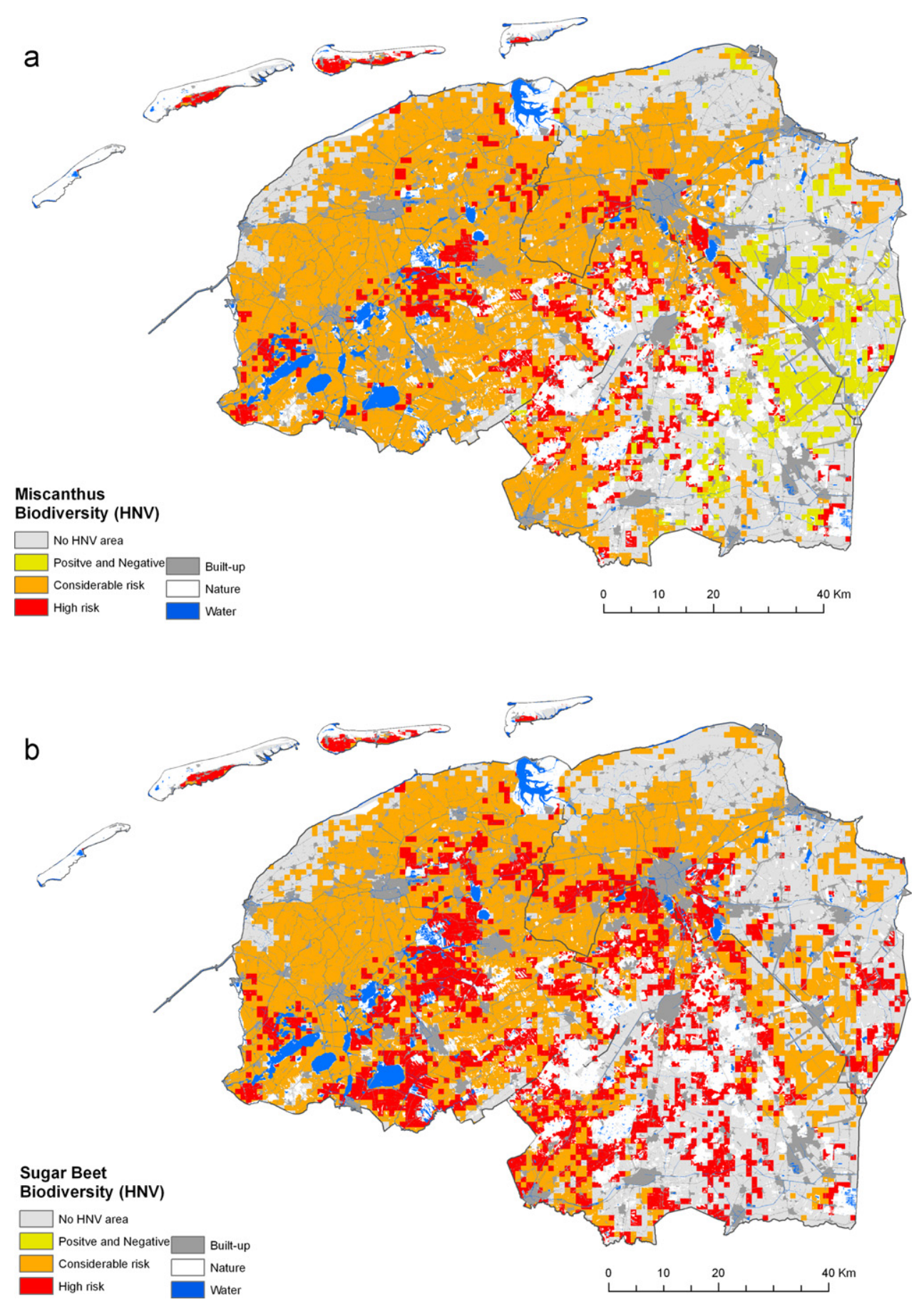

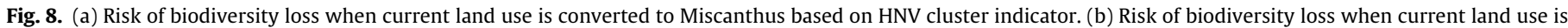
converted to sugar beet based on HNV cluster indicator.

negative impacts on the $\mathrm{NO}_{3}{ }^{-}$concentration, $\mathrm{P}$ balance, soil erosion and also biodiversity are relatively large. For the same reasons, Miscanthus (extensively managed crop) scores relatively well in this area. Sugar beet has the least negative impacts in the northern pasture areas on clay soils and negative impacts are partly balanced out by reduced risk of nutrient leakage and water consumption.

Comparing the integrated results of the environmental impacts assessed in this study with the results of the economic performance of sugar beet and Miscanthus in this region assessed in the study of Van der Hilst et al. [22], show that the areas with best environmental performance are also the areas with the least cost of production (in $€ G \mathrm{~J}_{\text {biomass }}{ }^{-1}$ ). These are the areas currently in use for intensive agriculture. However, in most of these areas bioenergy crops cannot compete with current land use as conventional crops have a better economic performance on these suitable soils. Based on the results of the environmental impacts and economic performance, an area of $24 \mathrm{kha}$ can be identified as most promising for Miscanthus as in these areas it could compete with current land use, it has relatively low production costs and has the least negative and also positive environmental impacts. This well exceeds the proportion of agricultural land that could become available for bioenergy crop production in 2015 (9.6 kha arable land and 1.5 kha pasture land in the considered region) as indicated in the Refuel study [26]. As the study of Hilst et al. [22] showed that sugar beet cannot compete 

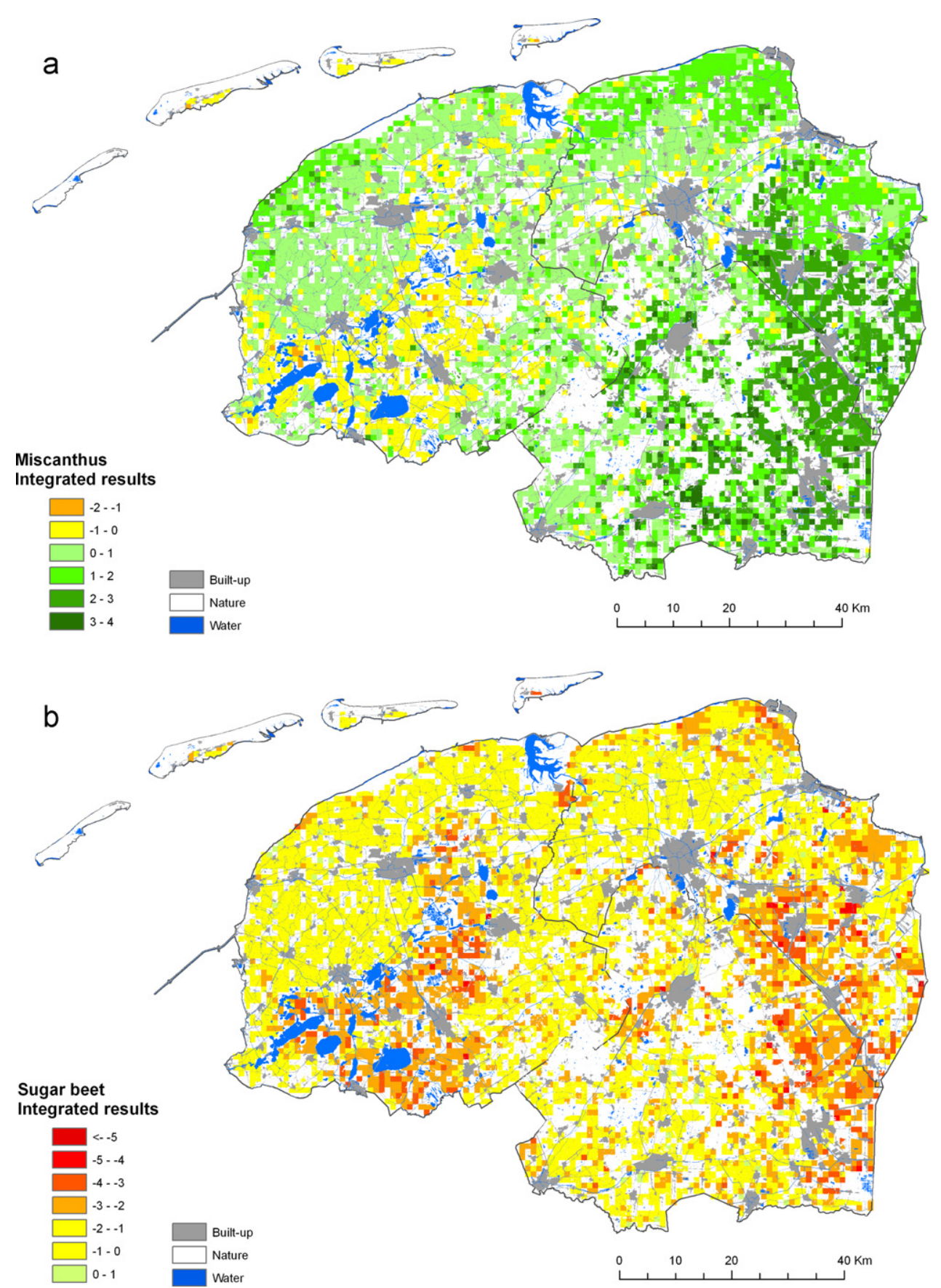

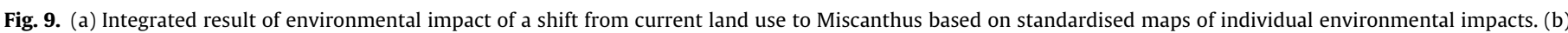
Integrated result of environmental impact of a shift from current land use to sugar beet based on standardised maps of individual environmental impacts.

with current land use and has relative high production costs in the whole agricultural area in the North of the Netherlands and this study shows mainly negative environmental impacts, it is assumed that sugar beet is not to be a promising bioenergy crop in this region.

\section{Discussion and conclusions}

Preferably, impacts would be assessed on most detailed spatial level. However, several input parameters of the Miterra model are only available on a postal code level. In addition, crop areas on a zip code level provides a proper indication of the crop mix in rotation, whereas a land cover recording of a single year on a detailed grid level ignores the effect of rotating crops. Furthermore, as there are uncertainties in several key input parameters such as crop management, leakage fraction per soil type, water surplus etc., impact assessment on a detailed grid level could give a too optimistic impression on the accuracy of the results. There are some drawbacks of the Miterra model: The fertiliserderived $\mathrm{N}_{2} \mathrm{O}$ emissions are calculated in accordance with the Tier 1 approach of the IPCC. However, as indicated by Smeets et al. [84] and Leschen et al. [85] this neglects the variability of emissions due to differences in environmental conditions, management and crop type. The Miterra Model includes only regional averages of climate data and in the calculation of leaching of nutrients and decomposition of organic matter, water surplus of precipitation was included but water table levels were neglected. Despite these shortcomings, the Miterra model was able to combine several spatial datasets in a consistent way and therefore provides excellent 
information on the relative differences in impacts on a spatially detailed level.

As indicated by Hoefnagels et al. [76], Cherubini et al. [88] and van Dam et al. [89], GHG balances of biofuels are very sensitive for assumptions regarding system boundaries, allocation methods and input parameters. Therefore, the results of the GHG assessment should be interpreted with care.

High soil losses due to wind erosion occur only incidentally when all relevant conditions are disadvantageous at the same time. By using an average monthly climate factor in the WEQ no accurate indication is provided on how often erosion thresholds are met. Although the WEQ is not the most sophisticated approach to assess the risk on erosion, it does provide a method to discriminate between crop covers and to assess the spatial variability in the erosion risk on a regional level. It is recommended to use actual field measurements and more exact models to spatially assess erosion risk on a regional level in order to achieve more accurate figures on the exact amount of soil loss.

The cumulative water deficit is assessed taking the spatial-temporal precipitation and evapotranspiration levels into account. It neglects however groundwater level, flow schemes of the water basin and the extensive water table regulation system. Therefore, the spatial water balance provides too little information to assess where actual droughts or water surpluses will occur. In order to assess the actual effect on water tables it is recommended that more advanced hydrologic models are applied.

In this study the HNV and MSA indicators were applied to identify areas with a high risk on biodiversity loss. The HNV approach enables to exclude the most vulnerable areas from a biodiversity perspective, which in line with the bioenergy sustainability criteria such as developed by RSB, RSPO, NTA8080. However, due to a lack of information on the response of species on the introduction of bioenergy crops, no quantitative assessment could be made. The MSA indicator on the other hand, enables to quantify the overall effect of a shift to bioenergy crops on biodiversity but because the MSA values does not account for diversity within a land use type, management practices or locally available biodiversity, the MSA provides little differentiation for agricultural land in the Netherlands.

In order to assess the impact on biodiversity in a quantitative way, we conclude in line with Rowe [18] that more empirical data are required on the impact of specific bioenergy crops on the occurrence of individual species.

The calculations of the environmental impacts are all based on a very broad range of input parameters. As the results are affected by the assumptions made on climate, soil, agronomy and management applied, they should be interpreted with care. However, as the assumptions are consistently applied, it provides a good indication the relative spatial differences in environmental impacts. As all impacts are related to ecosystem functionality, they are heavily interlinked with each other. In some cases, impacts reinforce each other and in other cases, trade offs between impacts occur. Although it is hard to prove causality and to quantify relations, it would be interesting to assess the spatial correlation between several impacts.

All environmental impacts of Miscanthus and sugar beet cultivation have been integrated in a standardised map of overall environmental performance. This required an interpretation of the dose-response relationship: to what extend is the caused effect a negative or positive impact. Both the dose-response relationship and the thresholds for actual damage are expected to be spatially heterogeneous, time related, and, in some cases, contradictive. In addition, cause-effect relationships could be linear, quadratic, exponential, inversely proportional, etc. As there is too little knowledge available of the dose-response relationship, a simple approach of maximum linear standardisation with no threshold was applied in this study. More expertise is required on the translation of a change in value of an indicator to an actual impact. This requires not only knowledge on physical relationships but also on the focal points of policy, the willingness to accept and the different points of view of the stakeholders involved. In the integration of environmental impacts all impacts were considered to be equally important, whereas ideally multiple perspectives from stakeholder on the hierarchy of environmental impacts would be included in a spatially explicit Multi Criteria Analysis (MCA).

This first explorative step could be further developed to an integrated assessment method by means of a stakeholder assessment and more advanced standardisation and weighting methods.

The integrated assessment shows that there are no areas in the North of the Netherlands where only positive effects occur when bioenergy crops are introduced and that there are several trade-offs between the impacts. In general, sugar beet causes relatively many negative environmental impacts especially in pasture areas. In these areas, the LUC related GHG emissions are up to $148 \mathrm{~kg} \mathrm{GJ}_{\text {ethanol }}{ }^{-1}$ and the risk on soil erosion increases to 9 ton ha ${ }^{-1}$. Also, there is a high risk on biodiversity loss in these areas. On the other hand, a shift towards sugar beet could cause a decrease of $75 \mathrm{mg} \mathrm{l}^{-1}$ in the $\mathrm{NO}_{3}{ }^{-}$concentration of groundwater and a decrease in the seasonal water deficits with $100 \mathrm{~mm}$. LUC to Miscanthus has less negative environmental impacts and in the areas currently in use as arable land many positive environmental impacts are expected to occur. In these areas, the LUC related GHG emissions are reduced by $-159 \mathrm{~kg} \mathrm{GJ}_{\text {ethanol }}{ }^{-1}$, the risk on soil erosion could be reduced with 4 ton ha ${ }^{-1}$, the $\mathrm{NO}_{3}{ }^{-}$ concentration is reduced with $53 \mathrm{mgl}^{-1}$, and the shift towards Miscanthus could have a positive contribution to biodiversity. On the other hand, at some locations the seasonal water depletion increases with $150 \mathrm{~mm}$ arable land is converted to Miscanthus. For both crops, the western wet pasture areas appear to be the area with most negative impacts. It can be concluded that the spatial correlation between impacts and current land use is higher than between impacts and soil type. The combination of the spatial distribution of the environmental impacts and the economic performance of sugar beet and Miscanthus assessed in the study of Van der Hilst et al. [22] shows that the areas with best environmental performance are also the areas with the least cost of production (in $€ \mathrm{GJ}_{\text {biomass }}{ }^{-1}$ ). Considering the large amount of negative impacts on areas currently in use as pastures, it could be recommended to exclude these areas for bioenergy crop production. In addition, as sugar beet causes relative many negative impacts, large scale introduction of this crop for bioenergy purposes should be carefully considered and implemented wisely.

This assessment has resulted in understanding in which areas the introduction of bioenergy is likely to cause severe environmental impacts and in which areas little negative and even positive effects are caused. This study well illustrates the high spatial variability of environmental impacts of potential bioenergy chains and therefore it stresses the importance to assess the sustainability of bioenergy supply chains in an integrated and spatially explicit way. This study provides a set of methodologies to assess the spatial variation of environmental impacts of bioenergy chains. Therefore, it contributes to identify promising locations for bioenergy production from an environmental point of view. Because of the generic characteristics, the methodologies and tools applied for this study can also be used for other case studies. It should be noted that this type of spatial explicit regional assessment on environmental impact of bioenergy chains cannot replace site specific environmental impact assessment. 


\section{Acknowledgements}

This study is part of the climate changes spatial planning program and is funded by the Dutch Government, the European Commission and Shell. The authors gratefully acknowledge the contribution of Saskia Visser (wur, soil centre) and Geert Sterk (landscape ecology, geo-informatics and hydrology; Utrecht University) for their expertise and information on (wind) erosion; Rob Sluiter, Raymond Sluiter and Jan Willem Nooteboom of the KNMI for their help to collect the required climatological data; Wilbert van Rooij, Marc van Oorschot, Rob Alkemade of PBL for sharing their knowledge about Mean Species Abundance and assessment methods; Berien Elbersen and Michiel van Eupen for their input on High Nature Value areas in the Netherlands; Iris Lewandowski for her knowledge and expertise about Miscanthus; Jan den Besten and Henk Norel for their expertise on water and water related problems in Hunze and Aa in Groningen; and Roland van Zoest of the GeoDesk Wageningen University for his help on GIS mapping of the climatological parameters.

\section{Appendix A. Supplementary data}

Supplementary data associated with this article can be found, in the online version, at doi:10.1016/j.rser.2012.01.027.

\section{References}

[1] Projectgroep 'Duurzame productie van Biomassa', Criteria voor duurzame biomassa productie. Task Force Energietranstie; 2006. p. 30.

[2] Commission of the European Communities. Directive of the European parliament and of the council on the promotion of the use of energy from renewable sources; 2008. p. $40+$ appendices.

[3] Fehrenbach H, Giegrich J, Reinhardt GA, Schmitz J, Sayer U, Gretz M, et al., on behalf of the Federal Environmental Agency. Criteria for a sustainable use of bioenergy on a global scale. Istitut fur energie- und umweltforschung Heidelberg, FSC Arbeitsgruppe Deutschland Freiburg, German Watch, DessauRosslau; 2008. p. $128+$ appendices.

[4] Gallagher E. The Gallagher review of the indirect effects of biofuels production. East Sussex: Renewable Fuels Agency; 2008. p. 90.

[5] ISCC. Sustainability requirements for the production of biomass; 2010, available from http://www.iscc-project.org/project [cited December 2009].

[6] Lewandowski I, Faaij APC. Steps towards the development of a certification system for sustainable bio-energy trade. Biomass Bioenergy 2006;30(2):83-104.

[7] van Dam J, Junginger M, Faaij APC, Jürgens I, Best G, Fritsche U. Overview of recent developments in sustainable biomass certification. Biomass Bioenergy 2008;32(8):749-80.

[8] van Dam J, Junginger M, Faaij APC. From the global efforts on certification of bioenergy towards an integrated approach based on sustainable land use planning. Renew Sustain Energy Rev 2010;14(9):2445-72.

[9] Blottnitz Hv, Curran MA. A review of assessments conducted on bio-ethanol as a transportation fuel from a net energy, greenhouse gas, and environmental life cycle perspective. J Cleaner Prod 2007;15(7):607-19.

[10] Kaltschmitt M, Reinhardt GA, Stelzer T. Life cycle analysis of biofuels under different environmental aspects. Biomass Bioenergy 1997;12(2):121-34.

[11] Lewandowski I, Heinz A. Delayed harvest of Miscanthus - influences on biomass quantity and quality and environmental impacts of energy production. Eur J Agron 2003;19(1):45-63.

[12] Hamelinck CN, van den Broek R. Participative LCA on biofuels. Utrecht: SenterNovem; 2005. p. 128.

[13] Malca J, Freire F. Renewability and life-cycle energy efficiency of bioethanol and bio-ethyl tertiary butyl ether (bioETBE): assessing the implications of allocation. Energy 2006;31(15):3362-80.

[14] Styles D, Jones MB. Energy crops in Ireland: quantifying the potential lifecycle greenhouse gas reductions of energy-crop electricity. Biomass Bioenergy 2007;31(11-12):759-72.

[15] van den Broek R, van den Burg T, van Wijk A, Turkenburg W. Electricity generation from eucalyptus and bagasse by sugar mills in Nicaragua: a comparison with fuel oil electricity generation on the basis of costs, macro-economic impacts and environmental emissions. Biomass Bioenergy 2000;19(5):311-35.

[16] Smeets E, Junginger M, Faaij A, Walter A, Dolzan P, Turkenburg W. The sustainability of Brazilian ethanol - an assessment of the possibilities of certified production. Biomass Bioenergy 2008;32(8):781-813.

[17] Smeets EMW, Faaij APC. The impact of sustainability criteria on the costs and potentials of bioenergy production - applied for case studies in Brazil and Ukraine. Biomass Bioenergy 2010;34(3):319-33.

[18] Rowe RL, Street NR, Taylor G. Identifying potential environmental impacts of large-scale deployment of dedicated bioenergy crops in the UK. Renew Sustain Energy Rev 2009;13(1):271-90.
[19] Börjesson P. Environmental effects of energy crop cultivation in Sweden - I: Identification and quantification. Biomass Bioenergy 1999;16(2):137-54.

[20] Börjesson P. Environmental effects of energy crop cultivation in Sweden - II: Economic valuation. Biomass Bioenergy 1999;16(2):155-70.

[21] van Dam J, Faaij APC, Hilbert J, Petruzzi H, Turkenburg WC. Large-scale bioenergy production from soybeans and switchgrass in Argentina: Part B. Environmental and socio-economic impacts on a regional level. Renew Sustain Energy Rev 2009;13(8):1679-709.

[22] Van der Hilst F, Dornburg V, Sanders JPM, Elbersen B, Graves A, Turkenburg WC, et al. Potential, spatial distribution and economic performance of regional biomass chains: the North of the Netherlands as example. Agric Syst 2010;103(7):403-17.

[23] EC. Directive 2009/28/EC of the European parliament and of the council on the promotion of the use of energy from renewable sources and amending and subsequently repealing Directives 2001/77/EC and 2003/30/EC; 2009.

[24] NEN. NTA 8080, Sustainability criteria for biomass for energy purposes. NEN; 2009.

[25] RSB. RSB principles \& criteria for sustainable biofuel production. Roundtable on Sustainable Biofuels; 2009. p. 28.

[26] de Wit M, Faaij A. European biomass resource potential and costs. Biomass Bioenergy 2010;34(2):188-202.

[27] Velthof GL, Oudendag D, Witzke HP, Asman WAH, Klimont Z, Oenema O. Integrated assessment of nitrogen losses from agriculture in EU-27 using MITERRA-EUROPE. J Environ Qual 2009;38(2):402-17.

[28] EC. Directive of the European parliament and of the council on the promotion of the use of energy from renewable sources; 2008. p. $40+$ appendices.

[29] JEC. Well-to-Wheels analysis of future automotive fuels and powertrains in the European context, version 3. European Council for Automotive R\&D (EUCAR), European Association for Environment, Health and Safety in Oil Refining and Distribution (CONCAWE), The Institute for Environment and Sustainability of the EU Commission's Joint Research Centre (JRC/IES); 2008.

[31] IPCC. Prepared by the National Greenhouse Gas Inventories Programme, Eggleston HS, Buendia L, Miwa K, Ngara T, Tanabe K., editors. IPCC guidelines for National Greenhouse Gas Inventories; 2006. Hayama, Kanagawa, Japan: IGES

[32] Velthof GL, Oudendag D, Oenema O. Development an dapplication of the integrated nitrogen model MITERRA-EUROPE. Wageningen: Alterra; 2007. p. 102 .

[33] Smeets EMW, Lewandowski IM, Faaij APC. The economical and environmental performance of Miscanthus and switchgrass production and supply chains in a European setting. Renew Sustain Energy Rev 2009;13(6-7):1230-45.

[34] van Dam J, Faaij APC, Hilbert J, Petruzzi H, Turkenburg WC. Large-scale bioenergy production from soybeans and switchgrass in Argentina: Part A: Potential and economic feasibility for national and international markets. Renew Sustain Energy Rev 2009;13(8):1710-33.

[35] Kuikman PJ, de Groot WJM, Hendriks RFH, Verhagen J, de Vries F. Stocks of $\mathrm{C}$ in Soils and Emissions of $\mathrm{CO}_{2}$ from agricultural soils in the Netherlands. Wageningen: Alterra, PRI; 2003. p. 39+ appendices.

[36] Reeves DW. The role of soil organic matter in maintaining soil quality in continuous cropping systems. Soil Tillage Res 1997:43(1-2):131-67.

[37] Romkes PFAM, Oenema O. Quick scan soils in the Netherlands, overview of the soil status with reference to the forthcomming EU soil strategy. Wageningen, The Netherlands: Alterra; 2004. p. 96.

[38] Pimentel D, Harvey C, Resosudarmo P, Sinclair K, Kurz D, McNair M, et al Environmental and economic costs of soil erosion and conservation benefits. Science 1995;267(5201):1117-23.

[39] USDA and NRCS. Soil quality resource concerns: soil erosion; 1996, available from http://soils.usda.gov/sqi/publications/files/sq_two_1.pdf.

[40] USDA and NRCS. National agronomy manual section 502 ed. Washington: United States Department of Agriculture, Natural Resource Conservation Service; 2002.

[41] Riksen MJPM, de Graaff J. On-site and off-site effects of wind erosion on European light soils. Land Degrad Dev 2001;12(1):1-11.

[42] van Kerckhoven S, Riksen MJPM, Cornelis W. Afbakening van gebieden gevoelig aan winderosie in Vlaanderen. Eindrapport. Gent, Belgium: Vakgroep Bodembeheer - Faculteit Bio-enginieurswetenschappen, Gent University; 2009. p. 79.

[43] Eppink LAAJ, Spaan WP. Agricultural wind erosion measures in the Netherlands Soil Technol Ser 1989;1:1-13.

[44] Riksen M, de Graaff J. On-site and off-site effects of wind erosion on European light soils. Land Degrad Dev 2001;12(1):1-11.

[45] Morgan RPC. Soil erosion and conservation. 3rd ed. Oxford: Blackwell Publishing Ltd; 2005, 304.

[46] Cramer J. Testing framework for sustainable biomass; final report from the project group “Sustainable production of biomass"; 2007. Commissioned by the Dutch Energy Transition's Interdepartmental Programme Management (IPM), p. 60 .

[47] de Fraiture C, Berndes G. Biofuels and water. In: Howarth RW, Bringezu S, editors. Biofuels: environmental consequences and interactions with changing land use. Proceedings of the Scientific Committee on Problems of the Environment (SCOPE) International Biofuels Project Rapid Assessment. Ithaca, NY USA: Cornell University; 2009. p. 139-53.

[48] Berndes G. Bioenergy and water - the implications of large-scale bioenergy production for water use and supply. Glob Environ Change 2002;12(4):253-71.

[49] Gerbens-Leenes W, Hoekstra AY, van der Meer TH. The water footprint of bioenergy. Proc Natl Acad Sci USA 2009;106(25):10219-23. 
[50] Dornburg V, van Vuuren D, van de Ven G, Langeveld H, Meeusen M, Banse M, et al. Bioenergy revisited: key factors in global potentials of bioenergy. Energy Environ Sci 2010;3(3):258-67.

[51] Bessembinder JJE, Leffelaar PA, Dhindwal AS, Ponsioen TC. Which crop and which drop, and the scope for improvement of water productivity. Agric Water Manage 2005;73(2):113-30.

[52] Brouwer C, Heibloem M. Irrigation water management: irrigation water needs. training manual no. 3. Part I - Principles of irrigation water needs. Rome, Italy: FAO, Natural Resources Management and Environment Department; 1986.

[53] Hoogeveen MW, Bommel KHMv, Cotteleer G. Beregening in land- en tuinbouw. Rapport voor de Droogtestudie Nederland. Den Haag: LEI; 2003. pp. 64.

[54] Dastane NG. Effective rainfall in irrigated agriculture. Rome, Italy: FAO; 1978.

[55] FAO. CROPWAT 8.0, Software tool to calculate evapotranpiration and irrigation requirements of crops. Rome, Italy: Land and Water Development Division of FAO; 2009.

[56] Hooghart JC, Lablans WN. Van Penman naar Makkink: een nieuwe berekeningswijze voor de klimatologische verdampingsgetallen. De Bilt: KNMI; 1988. p. 67.

[57] Buishand TA, Velds CA. In: Instituut KNM, editor. Neerslag en Verdamping. de Bilt: Koninklijk Nederlands Meteorologisch Instituut; 1980.

[58] Allan RG, Pereira LS, Raes D, Smith M. Crop evapotranspiration - guidelines for computing crop water requirements - FAO Irrigation and drainage paper 56. Rome, Italy: FAO; 1998.

[59] KNMI. Klimatatlas; Langjarige gemiddelden en extremen, tijdvak 1971-2000. KNMI; 2002.

[60] Fraters B, Boumans LJM, van Leeuwen TC, Reijs JW. De uitspoeling van het stikstofoverschot naar grond- en oppervlaktewater op landbouwbedrijven. Bilthoven: RIVM, LEI-Wageningen UR; 2007. p. 62 + appendices.

[61] Reidsma P, Tekelenburg T, van den Berg M, Alkemade R. Impacts of land-use change on biodiversity: an assessment of agricultural biodiversity in the European Union. Agriculture. Ecosyst Environ 2006;114(1):86-102.

[62] UNEP. Global environment outlook 3. Nairobi, Kenia: United Nations Environment Programme; 2002.

[63] Sala OE, Chapin III FS, Armesto JJ, Berlow E, Bloomfield J, Dirzo R, et al. Global biodiversity scenarios for the year 2100. Science 2000;287(5459):1770-4.

[64] Foley JA, de Fries R, Asner GP, Barford C, Bonan G, Carpenter SR, et al. Global consequences of land use. Science 2005;309(5734):570-4.

[65] Sala OE, Sax D, Leslie H. Biodiversity consequences of biofuel production. In: Howarth RW, Bringezu S, editors. Biofuels: environmental consequences and interactions with changing land use. Proceedings of the Scientific Committee on Problems of the Environment (SCOPE) International Biofuels Project Rapid Assessment. Ithaca, NY, USA: Cornell University; 2009. p. 127-37.

[66] Groom MJ, Gray EM, Townsend PA. Biofuels and biodiversity: principles for creating better policies for biofuel production. Conserv Biol 2008;22(3):602-9.

[67] Schlegel S, Elbersen BS, KaphengstF T. Input to DG TREN consultation on "Biofuel issues in the new legislation on the promotion of renewable energy". How to avoid major biodiversity loss from land use change induced by biomass production for bioenergy? Alterra: Ecologic - Institute for International and European Environmental Policy; 2007.

[68] Eggers J, Tröltzsch K, Falcussi A, Maiorano L, Verburg PH, Framstad E, et al. Is biofuel policy harming biodiversity in Europe? Global Change Biol Bioenergy 2009;1:18-34.

[69] EC. Guidance document. The application of the high nature value impact indicator 2001-2013. European Commission, Agriculture and Rural Development, The European Evaluation Network for Rural Development; 2009.
[70] Paracchini ML, Petersen J-E, Hoogeveen Y, Bamps C, Burfield I, van Swaay C. High nature value farmland in Europe. An estimate of the distribution patterns on the basis of land cover and biodiversity data. Luxembourg: European Comission Joint research Centre, European Environment Agency; 2008.

[71] Elbersen BS, van Eupen M. Landbouwgrond met hoge natuurwaarden in Nederland op de kaart. Wageningen: Alterra; 2008. p. 125.

[72] Alkemade R, van Oorschot M, Miles L, Nellemann C, Bakkenes M, ten Brink B. GLOBIO3: a framework to investigate options for reducing global terrestrial biodiversity loss. Ecosystems 2009;12(3):374-90.

[73] Secretariat of the Convention on Biological Diversity and Netherlands Environmental Assessment Agency. Cross-roads of life on earth - exploring means to meet the 2010 biodiversity target. Solution oriented scenarios for global biodiversity outlook 2. Montreal: Secretariat of the Convention on Biological Diversity; 2007. p. 90.

[74] MNP. In: Bouwman AF, Kram T, Klein Goldewijk K, editors. Integrated modelling of global environmental change: an overview of IMAGE 2.4. Bilthoven, The Netherlands: MNP; 2006. p. 228.

[75] Hamelinck CN, Hoogwijk M. Future scenarios for first and second generation biofuels. Utrecht Bilthoven: Ecofys MNP; 2007. p. 78.

[76] Hoefnagels R, Smeets E, Faaij A. Greenhouse gas footprints of different biofuel production systems. Renew Sustain Energy Rev 2010;14(7):1661-94.

[77] Bergsma G, Vroonhof J, Dornburg V. A greenhouse gas calculation methodology for biomass-based electricity, heat and fuels - the view of the Cramer Commission. Delft: CE Delft, Utrecht University; 2007. p. 39.

[78] Elsayed MA, Matthews R, Martimer ND. Carbon and energy balances for a range of biofuels options. Sheffield, UK: Sheffield Hallam University, Resources Research Unit; 2003. p. $25+$ appendices.

[79] Foereid B, de Neergaard A, Høgh-Jensen H. Turnover of organic matter in a Miscanthus field: effect of time in Miscanthus cultivation and inorganic nitrogen supply. Soil Biol Biochem 2004;36(7):1075-85.

[80] Schneckenberger K, Kuzyakov Y. Carbon sequestration under Miscanthus in sandy and loamy soils estimated by natural ${ }^{13} \mathrm{C}$ abundance. J Plant Nutr Soil Sci 2007; 170(4):538-42.

[81] Kort J, Collins M, Ditsch D. A review of soil erosion potential associated with biomass crops. Biomass Bioenergy 1998;14(4):351-9.

[82] Clifton-Brown JC, Lewandowski I. Water use efficiency and biomass partitioning of three different Miscanthus genotypes with limited and unlimited water supply. Ann Bot 2000;86(1):191-200.

[83] Council of the European Communities. Council directive of 12 December 1991 concerning the protection of waters against pollution caused by nitrates from agricultural sources. 91/676/EEC; 1991 .

[84] Smeets EMW, Bouwman LF, Stehfest E, van Vuuren DP, Posthuma A. Contribution of $\mathrm{N}_{2} \mathrm{O}$ to the greenhouse gas balance of first-generation biofuels. Global Change Biol 2009;15(1):1-23.

[85] Lesschen JP, Velthof GL, de Vries W, Kros J. Differentiation of nitrous oxide emission factors for agricultural soils. Environ Pollut 2011;159(11):3215-22.

[88] Cherubini F, Bird ND, Cowie A, Jungmeier G, Schlamadinger B, WoessGallasch S. Energy- and greenhouse gas-based LCA of biofuel and bioenergy systems: key issues, ranges and recommendations. Resour Conserv Recycl 2009;53(8):434-47.

[89] van Dam J, Faaij APC, Gustavsson L, Turkenburg WC. A unified methodology and tool to evaluate greenhouse gas balances and cost-effectiveness of various biomass energy systems. Chapter 6 . Sustainability of Bioenergy chains: the result is in the details. PhD Thesis. J. v. Dam. Utrecht, Copernicus Institute, Utrecht University, 2010. 